\title{
Three representative UK moorland soils show differences in decadal release of dissolved organic carbon in response to environmental change
}

\author{
M. I. Stutter ${ }^{1}$, D. G. Lumsdon ${ }^{1}$, and A. P. Rowland ${ }^{2}$ \\ ${ }^{1}$ The James Hutton Institute, Craigiebuckler, Aberdeen, UK \\ ${ }^{2}$ Centre for Ecology and Hydrology, Lancaster University, UK \\ Received: 5 July 2011 - Published in Biogeosciences Discuss.: 5 August 2011 \\ Revised: 16 November 2011 - Accepted: 24 November 2011 - Published: 14 December 2011
}

\begin{abstract}
Moorland carbon reserves in organo-mineral soils may be crucial to predicting landscape-scale variability in soil carbon losses, an important component of which is dissolved organic carbon (DOC). Surface water DOC trends are subject to a range of scaling, transport and biotic processes that disconnect them from signals in the catchment's soils. Long-term soil datasets are vital to identify changes in DOC release at source and soil C depletion. Here we show, that moorland soil solution DOC concentrations at three key UK Environmental Change Network sites increased between 1993-2007 in both surface- and sub- soil of a freely-draining Podzol ( $48 \%$ and $215 \%$ increases in $\mathrm{O}$ and Bs horizons, respectively), declined in a gleyed Podzol and showed no change in a Peat. Our principal findings were that: (1) considerable heterogeneity in DOC response appears to exist between different soils that is not apparent from the more consistent observed trends for streamwaters, and (2) freelydraining organo-mineral Podzol showed increasing DOC concentrations, countering the current scientific focus on soil $\mathrm{C}$ destabilization in peats. We discuss how the key solubility controls on DOC associated with coupled physico-chemical factors of ionic strength, acid deposition recovery, soil hydrology and temperature cannot readily be separated. Yet, despite evidence that all sites are recovering from acidification the soil-specific responses to environmental change have caused divergence in soil DOC concentration trends. The study shows that the properties of soils govern their specific response to an approximately common set of broad environmental drivers. Key soil properties are indicated to be drainage, sulphate and DOC sorption capacity. Soil properties need representation in process-models to understand and predict the role of soils in catchment to global $\mathrm{C}$ budgets. Catchment hydrological (i.e. transport) controls may, at
\end{abstract}

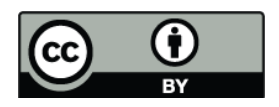

Correspondence to: M. I. Stutter (marc.stutter@hutton.ac.uk) present, be governing the more ubiquitous rises in river DOC concentration trends, but soil (i.e. source) controls provide the key to prediction of future $\mathrm{C}$ loss to waters and the atmosphere.

\section{Introduction}

Soils store large amounts of organic carbon $(1500 \mathrm{PgC}$ in the upper $1 \mathrm{~m}$; Batjes, 1996), estimated as three-times and twice that in above ground biomass and atmospheric pools, respectively (Eswaran et al., 1993). Dissolved organic C (DOC) is a rapidly cycling component of the soil carbon (C) pool and an important indicator of change in soil $\mathrm{C}$ stability, and in the contributing biogeochemical processes. At catchment scales the magnitude of soil DOC release relates closely to the soil C pool size (Hope et al., 1997). Upland areas with $\mathrm{C}$ rich soils are deemed sensitive indicators of environmental change and DOC a key parameter to observe. The extent and dynamics of DOC release are governed by inter-related physico-chemical and biological soil conditions, including the nature of the soil organic matter itself (Kalbitz et al., 2000). Spatio-temporal variability in DOC concentrations, composition and release rates present an important challenge for modeling the implications for $\mathrm{C}$ budgets, stream and soil ecosystems. DOC is a key component of $\mathrm{C}$ fluxes (Hope et al., 1997) and influences many ecosystem processes; mobilization, transport and bioavailability of nutrients, metals and organic contaminants (Lawlor and Tipping, 2003).

There has been widespread evidence for increasing catchment DOC concentrations across UK, US and Europe (Freeman et al., 2001; Worrall et al., 2004a; Skelkvåle et al., 2005; de Wit et al., 2007; Monteith et al., 2007). Positive monotonic trends are generally found for streamwater DOC (Monteith et al., 2007). As a result there has been considerable examination of the potential large-scale drivers (Evans et al., 2006), generally split between hypotheses of

Published by Copernicus Publications on behalf of the European Geosciences Union. 
the influences of declining acid sulphate deposition or climate change. Clean air acts in the US and Europe during 1970 's to 1990's have reduced acid $\mathrm{SO}_{4}^{2-}$ deposition onto soils (Stoddard et al., 2003). Experiments have implicated pollutant $\mathrm{SO}_{4}^{2-}$ deposition in suppressing DOC solubility (de Wit et al., 2001) and in turn, current increases in surface water DOC are the proposed response to the pollutant $\mathrm{SO}_{4}^{2-}$ declines (Monteith et al., 2007; Evans et al., 2008). An argument against this is that DOC concentrations have also decreased in eastern Canada where acid deposition has declined (Clair et al., 2008).

Alternatively, changes in rainfall amount, temperature and atmospheric $\mathrm{CO}_{2}$ have been offered as explanations for rising DOC concentrations in catchments (Freeman et al., 2001; Worrall et al., 2004; Eimers et al., 2008). Numerous studies show that soil warming accelerates organic carbon decomposition, assessed as respiration rates (Kirschbaum, 1995; Knorr, 2005). It has been proposed that attributing DOC trends between the dominant two drivers of declining atmospheric deposition and climate change is important since the former represents a return to pre-industrial DOC concentrations (i.e. recovery), but the latter a trajectory of destabilising soil C reserves (Evans et al., 2006). Clark et al. (2010) have tried to unify these competing theories for regional drivers of DOC. They conclude that the often contrasting studies are confounding a number of simultaneous processes operating differently at a range of spatial and temporal scales. It is unlikely that a single mechanism dominates DOC concentration change.

Part of this uncertainty in understanding and predicting the response of different systems to different changing environmental drivers is in the available scientific evidence. Comparing net chemical outputs in streams and lakes to precipitation inputs treats the catchment as a "black box" and does not adequately address the heterogeneous responses of soils to environmental pressures. Trends in surface water chemistry are many steps away from direct evidence of the changes actually occurring at the soil-water interface, notably due to the strong effects of catchment flowpath changes, flushing frequencies and intensities (Tranvik and Jannsson, 2002; Hongve et al., 2004). The fact that not all streamwaters show increasing DOC (Monteith et al., 2007) reinforces the need to look "inside the catchments". Given concerns over the bias of laboratory experiments compared to field data (Kalbitz et al., 2000), longer-term in-situ observations of soil DOC dynamics are fundamental to improving our understanding of $\mathrm{C}$ cycling. We have compiled metadata on the limited number of published long-term studies of soil solution DOC (Table 1), especially sparse for non-forested systems. This contrasts with the much larger population of stream water DOC studies compiled by Clark et al. (2010). These are dominated by positive DOC concentration trends ( $72 \%$ of 1149 sites) and show considerable disparity in the proposed drivers.

Here we report long-term monitoring data of in-situ soil solutions, with associated streamwater, deposition and climate data from three UK Environmental Change Network sites (Glensaugh, GS; Sourhope, SH; Moor House, MH). These data have, in part, been scrutinized previously for different purposes, namely evaluating shorter-term trends in UK topsoil DOC (Buckingham et al., 2008), effects of sulphate oxidation in the well-studied Moor House system (Clark et al., 2005) and geochemical modeling at Glensaugh (Lumsdon et al., 2005). Never previously have long-term soil solution trends for surface and subsoils been compared across three distinct moorland systems. The premise of our investigation is that soil solutions are more sensitive indicators of how catchment DOC sources respond to environmental change than surface waters, especially in terms of changing susceptibility for DOC release (production and solubility). Using this soil solution data we aim to: (i) evaluate differences in DOC and accompanying solute trends for three soils of contrasting properties to highlight key soils releasing DOC and inform spatio-temporal variability in catchment losses, and (ii) assess how different soil properties contribute to any differences in the DOC responses to key biogeochemical drivers for which we have accompanying data, namely atmospheric deposition and basic climate factors.

\section{Materials and methods}

\subsection{Site descriptions and Monitoring Program}

Glensaugh (GS), Sourhope (SH) and Moorhouse (MH) are characteristic UK upland moorland sites that are operated as part of a wider UK Environmental Change Network (http: //www.ecn.ac.uk/sites.htm). This network has selected sites that are susceptible to changes due to wider environmental change pressures (typified by climate and deposition) whilst management is maintained as representative for the ecosystems. Catchment, deposition history and soil properties for the sites are summarised in Table 2. All three catchments comprise semi-natural moorland used for extensive grazing. GS and $\mathrm{MH}$ are dominated by heather moorland, and SH grassland. Soils at all sites are of base cation deficient parent materials and dominated by organic and organo-mineral soils. Hence, these landscapes typify those of key concern for soil carbon and river DOC management at these latitudes.

Our observations during 1993-2007 span a crucial period when UK emissions of $\mathrm{SO}_{2}$ declined by $70 \%$ following the decline from a peak of industrial sulphate emissions in the 1980's (Fowler et al., 2005). Establishment and monitoring of biological, chemical and hydrological factors commenced across the network through the 1990's. Monitoring commenced first in 1992-1993 for the three sites GS, SH and $\mathrm{MH}$, with others beginning much later and with more fragmented records. Hence, our analyses are limited to these three sites, their associated soils and waters with the longest records. 
Table 1. Published analyses of DOC trends (linear methods) for soil solutions with site characteristics. Arrows with symbols $\downarrow$, $\uparrow$ and $\leftrightarrow$ denote concentration trends showing significant decrease, increase or no significant change, respectively (with the number of sites in each trend category).

\begin{tabular}{|c|c|c|c|c|c|c|c|c|}
\hline Country & Ecosystem $(n)$ & $\begin{array}{l}\text { Peak S deposition } \\
\left(\mathrm{kgS} \mathrm{ha}^{-1} \mathrm{yr}^{-1}\right)\end{array}$ & Soil type $(n)$ & Period & Depth (Horizon) & Sulphate trend & DOC trend & Ref \\
\hline Sweden & Forest (27) & $\sim 12$ & $\begin{array}{l}\text { Podzol (17) } \\
\text { Gleysol (6) } \\
\text { Histosol (4) }\end{array}$ & 1996-2007 & $\begin{array}{l}13-50 \mathrm{~cm} \\
(\mathrm{O}, \mathrm{E}, \mathrm{B})\end{array}$ & $\begin{array}{l}\text { Generally } \\
\text { decreased } \\
\text { considerably }\end{array}$ & $\begin{array}{l}\downarrow(10), \leftrightarrow(16), \uparrow \\
(1)\end{array}$ & $\mathrm{a}$ \\
\hline Norway & Forest (13) & & $\begin{array}{l}\text { Podzol (4) } \\
\text { Cambisol (2) } \\
\text { Leptosol (2) } \\
\text { Arenosol (1) }\end{array}$ & 1996-2006 & $\begin{array}{l}5 \mathrm{~cm} \\
15 \mathrm{~cm} \\
40 \mathrm{~cm}\end{array}$ & $\begin{array}{l}\downarrow(3), \leftrightarrow(5) \\
\downarrow(3), \leftrightarrow(4) \\
\downarrow(5), \leftrightarrow(4)\end{array}$ & $\begin{array}{l}\leftrightarrow \\
\downarrow(5), \leftrightarrow(5), \uparrow(1) \\
\downarrow(2), \leftrightarrow(11)\end{array}$ & $\mathrm{b}$ \\
\hline UK & $\begin{array}{l}\text { Moorland (2) } \\
\text { Forest (7) }\end{array}$ & & $\begin{array}{ll}\text { Podzol } & (4), \\
\text { Histosol } & (1), \\
\text { Gleysol } & (2), \\
\text { Other (2) } & \end{array}$ & 2000-2005 (minimum 3 years) & $10 \mathrm{~cm}$ & nd & $\leftrightarrow(2), \uparrow(7)$ & $\mathrm{c}$ \\
\hline Czech Republic & Forest (2) & $30-40$ & $\begin{array}{l}\text { Podzol (1) } \\
\text { Cambisol (1) }\end{array}$ & 1994-2007 & $\sim 5 \mathrm{~cm}(\mathrm{O}, \mathrm{A})$ & $\downarrow$ & $\uparrow$ & $\mathrm{d}$ \\
\hline
\end{tabular}

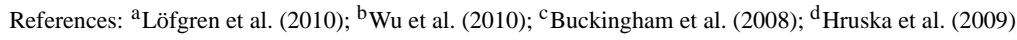

$n=$ denotes the number of sites in each category.

\subsection{Sampling methods}

Soil solutions were sampled fortnightly by tension lysimetry using Prenart Super Quartz samplers (Prenart, Frederiksberg, Denmark). These samplers (dimensions $21 \mathrm{~mm}$ by $95 \mathrm{~mm}$ ) comprise 50\% PTFE and 50\% quartz and are designed not to retain organic carbon, unlike ceramic types. Environmental Change Network (ECN) protocols dictated that samplers were placed at the base of $\mathrm{O}$ horizons and $\mathrm{B}$ horizons, except for deep peats where fixed depths of 10 and $50 \mathrm{~cm}$ depths were used. Soil solutions are hereby termed "shallow" and "deep" at each site. Stream chemistry, discharge and climate variables were also available. The ECN network provides consistent, standardised methodologies (http: //www.ecn.ac.uk/protocols/index.asp), which gives validity to between-site comparisons in trends. Streamwater, soil water and bulk deposition samples were analysed for $\mathrm{pH}$ and conductivity, then filtered $(<0.45 \mu \mathrm{m})$ and analysed for DOC by combustion oxidation and IR gas detection, total metals (Al, $\mathrm{Ca}, \mathrm{Fe}, \mathrm{K}, \mathrm{Mg}, \mathrm{Na}$ ) by ICP-OES, $\mathrm{Cl}^{-}, \mathrm{SO}_{4}^{2-}$ by Dionex ion chromatography, $\mathrm{NO}_{3}^{-}, \mathrm{PO}_{4}^{3-}, \mathrm{NH}_{4}^{+}$and alkalinity colorimetrically. Each site has one nest of six soil solution samplers located on a single soil type that is dominant at, or typical to each site. Hence, our analyses are restricted to three contrasting soils, a freely-draining Podzol (GS), restricteddrainage gleyed Podzol (SH) and Histosol (MH), one soil at each of the sites. Bulk deposition hydrochemistry collectors and rain gauges are located at stream gauging points. Climate data, including soil temperature, are logged automatically adjacent to the soil solution locations at each site, nearby and within the hydrologic catchments (Table 2).

\subsection{Analyses of trends in monitoring data}

Mean soil solute concentrations were calculated over each sites' $30 \times 30 \mathrm{~m}$ soil solution collection plots $(n=6)$ by volume weighting using the collected volumes from each sampler. Commonly, during dry periods, sample volumes from individual samplers were too small to analyse and were pooled for analyses. Our calculations of volume-weighted mean from individual sampler concentrations ensured a consistent approach during dry and wet periods. We confirmed that sampler volumes at Glensaugh were significantly related to soil moisture determined by in-situ theta probes. Climate and hydrochemical data were used without averaging, whilst hourly means were calculated for analyses of trends in soil temperature, rainfall volume and stream discharge. Trend analyses of measured and modelled time-series were performed using the seasonal Mann-Kendall (MK) test for monotonic trends (Hirsch and Slack, 1984). Month was the class variable and the median, annual slope and significance were derived from the MK statistic using the Sen slope estimator.

We also undertook a simple assessment using linear multiple regression models predicting shallow and deep soil solutions and stream water DOC concentrations $(n=14)$ using a possible set of predictors of rainfall sulphate concentration, soil temperature at $10 \mathrm{~cm}$ depth, rainfall amount and combinations of the above. In order to remove the effects of seasonality (which would have produced a high degree of autocorrelation between some variables) we used median annual data for the fourteen years. This approach was similar to that previously applied by Evans et al. (2006) for the UK Acid waters Monitoring Network lakes.

We calculated output (stream) minus input (deposition) catchment budgets for sulphate. Deposition flux was 
Table 2. Site and soil characteristics.

\begin{tabular}{|c|c|c|c|c|c|c|}
\hline & \multicolumn{2}{|c|}{ Glensaugh (GS) } & \multicolumn{2}{|c|}{ Sourhope (SH) } & \multicolumn{2}{|c|}{ Moor House (MH) } \\
\hline Location & \multicolumn{2}{|c|}{$57^{\circ} \mathrm{N}, 3^{\circ} \mathrm{W}$} & \multicolumn{2}{|c|}{$55^{\circ} \mathrm{N}, 3^{\circ} \mathrm{W}$} & \multicolumn{2}{|c|}{$54^{\circ} \mathrm{N}, 2^{\circ} \mathrm{W}$} \\
\hline Catchment area $\left(\mathrm{km}^{2}\right)$ & \multicolumn{2}{|l|}{0.8} & \multicolumn{2}{|l|}{0.4} & \multicolumn{2}{|l|}{11.4} \\
\hline $\begin{array}{l}\text { Median altitude (m) } \\
\text { Bulk deposition }{ }^{\mathrm{a}} \text { : } \\
\text { Rain }(\mathrm{mm}) \\
\text { keqSO }_{4}-\mathrm{Sha}^{-1} \mathrm{yr}^{-1} \\
\text { keqNO }_{3}-\mathrm{N} \mathrm{ha}^{-1} \mathrm{yr}^{-1}\end{array}$ & $\begin{array}{l}1040 \\
0.60 \\
0.36\end{array}$ & $\begin{array}{l}p=0.003) \\
d, p=0.1)\end{array}$ & $\begin{array}{l}1015 \\
0.45 \\
0.21\end{array}$ & $\begin{array}{c}p=0.03) \\
\mathrm{d}, p=0.2)\end{array}$ & $\begin{array}{l}1900 \\
0.78 \\
0.88\end{array}$ & $\begin{array}{l}\text { d, } p=0.4) \\
d, p=0.7)\end{array}$ \\
\hline Soil temp $\left({ }^{\circ} \mathrm{C}\right)^{\mathrm{b}}$ & \multicolumn{2}{|c|}{$6.7(+0.06, p=0.02)$} & \multicolumn{2}{|c|}{8.2 (no trend, $p=0.4$ ) } & \multicolumn{2}{|c|}{5.9 (no trend, $p=0.2$ ) } \\
\hline Vegetation & \multicolumn{2}{|c|}{$\begin{array}{l}\text { Heather moorland } \\
\text { Calluna vulgaris, } \\
\text { Vaccinium myrtillus }\end{array}$} & \multicolumn{2}{|c|}{$\begin{array}{l}\text { Coarse grassland } \\
\text { Nardus stricta } \\
\text { Molinia caerulea }\end{array}$} & \multicolumn{2}{|c|}{$\begin{array}{l}\text { Heather moorland } \\
\text { Eriophorum vaginatum, } \\
\text { Calluna vulgaris }\end{array}$} \\
\hline Soil parent material & \multicolumn{2}{|c|}{ Schistose drift } & \multicolumn{2}{|c|}{ Andesitic drift } & \multicolumn{2}{|c|}{ Limestone, shale } \\
\hline Soil type & \multicolumn{2}{|c|}{ Humus iron podzol } & \multicolumn{2}{|c|}{ Peat gleyed podzol } & \multicolumn{2}{|c|}{ Deep peat } \\
\hline $\begin{array}{l}\text { Horizon } \\
\text { Approx. depth }(\mathrm{cm})\end{array}$ & $\begin{array}{c}\mathrm{O} \\
10\end{array}$ & $\begin{array}{l}\text { Bs } \\
30\end{array}$ & $\begin{array}{c}\mathrm{O} \\
10\end{array}$ & $\begin{array}{c}\text { B } \\
40\end{array}$ & $\begin{array}{c}\mathrm{O} \\
10\end{array}$ & $\begin{array}{c}\mathrm{O} \\
50\end{array}$ \\
\hline $\mathrm{pH}_{\mathrm{CaCl}_{2}}$ & 3.1 & 3.9 & 3.1 & 3.4 & 2.9 & 3.0 \\
\hline $\begin{array}{l}\operatorname{Org} C\left(\mathrm{~g} \mathrm{~kg}^{-1}\right) \\
\left(\mathrm{g} \mathrm{cm}^{-3}\right)\end{array}$ & $\begin{array}{r}190 \\
0.08\end{array}$ & $\begin{array}{c}51 \\
0.07\end{array}$ & $\begin{array}{l}477 \\
0.14\end{array}$ & $\begin{array}{c}151 \\
0.18\end{array}$ & $\begin{array}{l}465 \\
0.09\end{array}$ & $\begin{array}{l}479 \\
0.14\end{array}$ \\
\hline $\mathrm{C}: \mathrm{N}$ & 25 & 23 & 20 & 21 & 32 & 31 \\
\hline Exch. BC (meq kg $\left.{ }^{-1}\right)^{\mathrm{c}}$ & 26.1 & 3.9 & 42.9 & 6.9 & 124 & 116 \\
\hline Exch. Al (meq kg-1) & 1.7 & 14.1 & 2.8 & 10.8 & nd & nd \\
\hline$\% \mathrm{BC}$ saturation & 5.5 & 1.7 & 5.1 & 1.8 & nd & nd \\
\hline Total S $\left(\mathrm{g} \mathrm{kg}^{-1}\right)$ & 1.0 & 0.4 & 3.5 & 0.8 & nd & nd \\
\hline $\mathrm{Al}_{\mathrm{Ox}}\left(\mathrm{g} \mathrm{kg}^{-1}\right)^{\mathrm{d}}$ & nd & 9.9 & nd & 9.5 & nd & nd \\
\hline $\mathrm{Fe}_{\mathrm{ox}}\left(\mathrm{g} \mathrm{kg}^{-1}\right)^{\mathrm{d}}$ & nd & 21.9 & nd & 2.9 & nd & nd \\
\hline
\end{tabular}

${ }^{\mathrm{a}}$ Deposition loads of $\mathrm{SO}_{4}$ and $\mathrm{NO}_{3}$ show the 1993 site load with the rate and significance of the linear regression annual decline (as kg ha ${ }^{-1}$ per year, $\left.n=14\right)$; ${ }^{\mathrm{b}}$ Soil temperature shows the median $10 \mathrm{~cm}$ depth daily temperature with the Mann-Kendall annual trend and significance $(n=5000) ;{ }^{\mathrm{c}} 1 \mathrm{M}$ Ammonium acetate extracts of soil base cations $(\mathrm{BC}) ;{ }^{\mathrm{d}}$ Acid ammonium oxalate extracts; end, not determined.

determined as the annual sum of concentration multiplied by volume for the weekly bulk deposition samples scaled to the catchment area. The continuous discharge record and weekly sample concentration data were used to calculate annual stream fluxes using the interpolation method "flux method 5" (Walling and Webb, 1985):

Total load $=K \frac{\sum_{i=1}^{n} \mathrm{CiQi}}{\sum_{i=1}^{n} \mathrm{Qi}} \overline{\mathrm{Q}}$

where $K$ is a conversion factor to account for the period of measurement, $\bar{Q}$ is the mean annual discharge (taken from the continuous hourly record over calibrated flume channels), $\mathrm{C}_{\mathrm{i}}$ and $\mathrm{Q}_{\mathrm{i}}$ are instantaneous concentrations and discharge respectively and $\mathrm{n}$ is the number of samples. Flow-weighted mean concentrations $\left(\overline{\mathrm{C}_{\mathrm{Q}}}\right)$ of stream water $\mathrm{DOC}$ were calculated according to:

$\overline{\mathrm{C}_{\mathrm{Q}}}=\frac{1}{n} \sum_{\mathrm{i}=1}^{n} \mathrm{Ci} \cdot \mathrm{Qi}^{*}$

where:

$\mathrm{Qi}^{*}=\frac{\mathrm{Qi}}{\overline{\mathrm{Q}}}$ 


\subsection{Geochemical modelling}

Concentrations of non-marine $(\mathrm{nm} \mathrm{X})$ components of the solutes $\mathrm{SO}_{4}^{2-}, \mathrm{Ca}^{2+}, \mathrm{K}^{+}, \mathrm{Mg}^{2+}$ and $\mathrm{Na}^{+}$were calculated according to: ${ }_{\mathrm{nm}} \mathrm{X}=\mathrm{X}-\left(\mathrm{Cl}^{-} / R\right)$, where $R$ was the seawater mass concentration ratio of $\mathrm{Cl}^{-}: \mathrm{X}(21.5,47.2,49.5,15.0,1.8$ for $\mathrm{SO}_{4}^{2-}, \mathrm{Ca}^{2+}, \mathrm{K}^{+}, \mathrm{Mg}^{2+}$ and $\mathrm{Na}^{+}$, respectively). Occasional negative values for concentrations of ${ }_{n m} R$ represented net uptake onto soil exchange sites.

The model NICA (Non-Ideal Competitive Adsorption)Donnan, within the ORCHESTRA modelling framework (Meeussen, 2003), was used for chemical speciation of soil waters. The NICA-Donnan model has been described elsewhere in a recent application of the model to Glensaugh $\mathrm{O}$ horizon data (Lumsdon et al., 2005). For soil solutions interacting with highly organic soil surfaces the model accounts for the competitive specific sorption of protons, $\mathrm{Al}$ and base cations and for the non-specific sorption into the "Donnan layer" of charged ions. From the solution species and their distribution between solid and solution phases the surface charge of the organic matter measured in solution is determined. The measured chemistry data was processed by modelling to produce the following output of chemical species at each time step for the soil waters:

1. cations: $\mathrm{H}^{+}, \mathrm{Na}^{+}, \mathrm{K}^{+}, \mathrm{NH}_{4}^{+}, \mathrm{Ca}^{2+}, \mathrm{Mg}^{2+}, \mathrm{Fe}^{3+}$, $\mathrm{Fe}(\mathrm{OH})^{2+}, \mathrm{Fe}\left(\mathrm{SO}_{4}\right)^{+}, \mathrm{Al}^{3+}, \mathrm{Al}(\mathrm{OH})^{2+}, \mathrm{Al}\left(\mathrm{SO}_{4}\right)^{+}$

2. anions: $\mathrm{Cl}^{-}, \mathrm{NO}_{3}^{-}, \mathrm{H}_{2} \mathrm{PO}_{4}^{-}, \mathrm{HCO}_{3}^{-}, \mathrm{CO}_{3}^{2-}, \mathrm{H}\left(\mathrm{SO}_{4}\right)^{-}$, $\mathrm{SO}_{4}^{2-}, \mathrm{H}\left(\mathrm{PO}_{4}\right)^{2-}$

Hence, the model calculated phosphate, sulphate, $\mathrm{Al}$ and $\mathrm{Fe}$ species from their measured totals, plus species of the carbonate equilibrium. Other constituents were measured. Inorganic $\mathrm{Al}\left(\mathrm{Al}_{\text {inorg }}\right)$ was calculated from measured total $\mathrm{Al}$ $\left(\mathrm{Al}_{\text {total }}\right)$ following subtraction of organically-complexed $\mathrm{Al}$ $\left(\mathrm{Al}_{\text {inorg }}\right)$ as derived using NICA-Donnan. Fe distribution was calculated similarly to Al. Charge on the DOC (hereby termed $\mathrm{Z}^{-}$; as mmol of charge per $\mathrm{g}$ of DOC) was calculated using NICA-Donnan (Lumsdon et al., 2005) and the portion of the ion balance associated with DOC (DOC.Z; eq $\mathrm{L}^{-1}$ ) was calculated as $\mathrm{Z}^{-}$multiplied by DOC concentration $\left(\mathrm{mgCL} \mathrm{L}^{-1}\right)$.

Model validation of chemical species was undertaken by assessing the charge balance of the calculated species:

Charge balance $=$ Sum of inorganic cations $-($ Sum of inorganic anions + DOC.Z).

Consistently small positive mean values for ion balance indicate generally slight anion deficiencies. The magnitudes of mean ion imbalances relative to mean ionic strengths were 2$11 \%$ (see Supporting Information Table S1 and Fig. S1). We were unable to undertake this modelling on the Moor House deep soil solutions which remains anoxic as the water table never rises above $45 \mathrm{~cm}$ deep. Consequently, there were large discrepancies in the cation vs. anion balance at MH deep.

\section{Results}

Trends in the data are examined in the order: atmospheric deposition, soil solutions and stream waters to follow the logical order of evaluating inputs, internal processes and transfer of signals to drainage water outputs. Median concentrations, trend significance and magnitude are given in Table 3, with selected trends depicted in Fig. 1. Lowess-smoothed trend lines are plotted for clarity and since we are concerned primarily with long-term change.

\subsection{Solute concentration trends in deposition chemistry}

The only consistent trends in deposition between all the sites were for declines in deposition $\mathrm{SO}_{4}$ concentrations and these were comparable in magnitude between sites. Deposition $\mathrm{pH}$ only increased significantly at Moorhouse $(+0.02 \mathrm{pH}$ units year $\left.^{-1}\right)$. There were overall decreases in deposition base and acid cations and acid anions at GS and SH representing a strong overall dilution in bulk deposition chemistry. Trends in $\mathrm{Cl}$ and $\mathrm{NO}_{3}$ deposition concentrations were inconsistent between sites. Sulphate deposition flux showed a significant linear decrease at GS and SH, but not MH (Table 2).

\subsection{Solute concentration trends in soil solutions}

Soil solution trends showed the MH Histosol had no significant DOC concentration trend at either depth, the $\mathrm{SH}$ gleyed Podzol had no significant DOC concentration trend in the organic horizon and a $23 \%$ overall decrease in the mineral horizon. However, in the freely-draining podzol at GS soil solution DOC concentrations increased significantly, amounting to $48 \%$ and $215 \%$ increases in the organic and mineral horizons, respectively.

Soil sulphate concentrations, declined substantially in both GS and SH soils at greater rates than in deposition or streamwaters (Fig. 1). This was concurrent to decreases in total $\mathrm{Al}$ for both soil horizons at GS and $\mathrm{SH}$ and increases in $\mathrm{pH}$ of mineral soil solutions at these sites. At $\mathrm{MH}$ soil $\mathrm{pH}$ increased in both shallow and deep O horizons, but sulphate showed short periods of greatly elevated sulphate concentrations normally associated with droughts. All soils showed generally decreased base cation solute concentrations, similar to trends in the deposition inputs. We found no evidence of long-term trends in electrical conductivity (EC; a direct measurement of ionic strength) in the GS organic, mineral, or SH organic soils ( $p=0.9,0.2,0.3$, respectively; data not shown). However, decreasing EC (3\% annually; $p=0.07$ ) in the SH mineral soil coincided with decreasing DOC concentrations.

The pronounced change in DOC concentration for the GS subsoils occurred mainly as a "step-change" (Fig. 2), that followed a drought year in 2003 (631 mm rainfall). Accompanying this, a pulse of acidity, $\mathrm{SO}_{4}^{2-}$ and $\mathrm{Al}$ occurred in the GS soil as the catchment rewet. Subsequently a new state of 

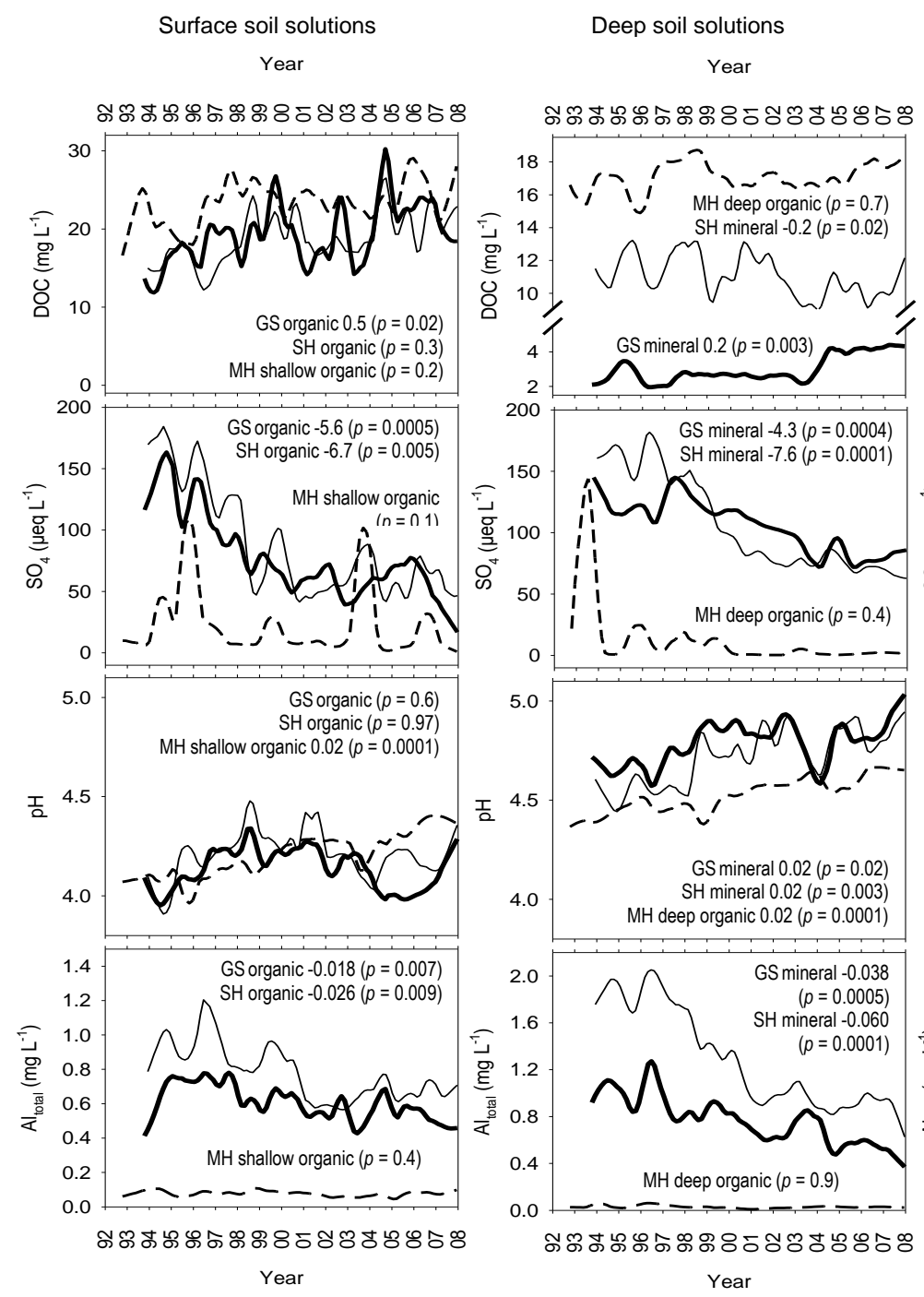
Streamwater (and deposition)
Year

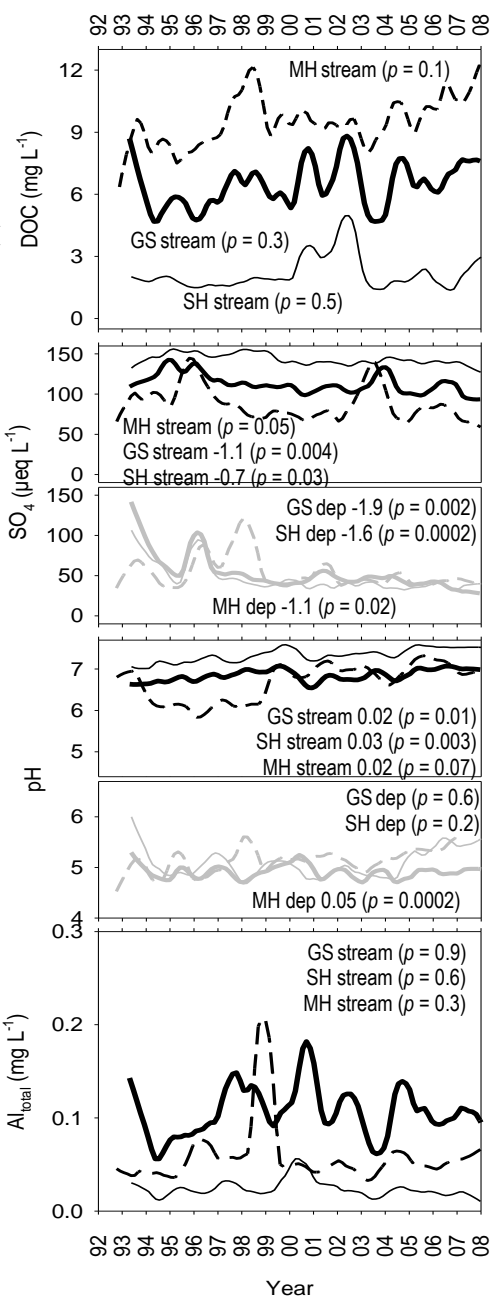

Fig. 1. Trends in solute concentrations of catchment waters. Lowess-smoothed solute concentration trends for surface organic, mineral/deep organic soil horizons, streamwaters and deposition (dep). Line notations are: Glensaugh (GS), bold solid line, Sourhope (SH), narrow solid line, Moorhouse $(\mathrm{MH})$, bold dashed line. For $\mathrm{SO}_{4}$ and $\mathrm{pH}$ only deposition concentrations are shown in grey lines. Statistical values for each line indicate significant rates of annual change according to Mann-Kendall analysis (with significance as $p$ value). The units of annual change are the same as concentration units (y axes) of the plots (and for $\mathrm{pH}$ units in the case of $\mathrm{pH}$ ).

DOC solubility was attained, over which the rising concentration trend continued.

\subsection{Solute concentration trends in stream waters}

Our Mann-Kendall analysis of weekly streamwater DOC concentrations found no significant trend at GS, SH and MH (Fig. 1). Linear regressions of annual flow-weighted mean stream water DOC concentrations did however show significant DOC increases at all sites (Fig. 3). Increases in $\mathrm{pH}$ of streamwaters were comparable between sites. Nitrate concentrations increased for stream waters at GS and $\mathrm{SH}$, even though no change in soil $\mathrm{NO}_{3}^{-}$occurred.
Mann-Kendall analysis showed $\mathrm{SO}_{4}^{2-}$ concentrations declined significantly in GS and SH streamwaters, but not at $\mathrm{MH}$ (Fig. 1). Thus, stream $\mathrm{SO}_{4}^{2-}$ concentration trends followed the same patterns as the respective catchments' soils, but with substantially smaller magnitude of change. Linear regression of annual stream $\mathrm{SO}_{4}^{2-}$ fluxes showed weak decreases with time that were not significant (data not shown: $p=0.08,0.4$ and 0.1 for GS, SH and MH, respectively). Sulphate mass-balances were positive for all catchments. The factor by which streamwater outputs exceeded deposition inputs was 2.1, 3.3 and 1.8 for GS, SH and MH, respectively. It is important to note that at GS a significant linear increase in catchment net sulphate output was evident ( $p=0.05$ ). 
Table 3. Temporal trend analyses using ordinary Mann-Kendall tests for monotonic trends in solute concentrations for ECN soil solutions (fortnightly data), deposition and stream chemistry (weekly data). Median concentrations and trends, where significant, are given as mg $\mathrm{L}^{-1}$, (except for $\mathrm{H}$ as $\mu \mathrm{M}$ ).

\begin{tabular}{|c|c|c|c|c|c|c|c|c|c|c|c|c|c|}
\hline & & \multicolumn{3}{|c|}{ Soil shallow } & \multicolumn{3}{|c|}{ Soil deep } & \multicolumn{3}{|c|}{ Deposition } & \multicolumn{3}{|c|}{ Stream water } \\
\hline \multicolumn{2}{|l|}{ Site } & \multirow{2}{*}{$\begin{array}{l}\text { Median } \\
75.89\end{array}$} & \multicolumn{2}{|c|}{ Trend } & \multirow{2}{*}{$\begin{array}{l}\text { Median } \\
16.27\end{array}$} & \multicolumn{2}{|c|}{ Trend } & \multirow{2}{*}{$\begin{array}{l}\text { Median } \\
15.72\end{array}$} & \multicolumn{2}{|r|}{ Trend } & \multirow{2}{*}{$\begin{array}{l}\text { Median } \\
0.13\end{array}$} & \multicolumn{2}{|c|}{ Trend } \\
\hline GS & $\mathrm{H}^{+} \mu \mathrm{M}$ & & & ns & & -0.65 & $\mathrm{c}$ & & & ns & & -0.01 & $\mathrm{~b}$ \\
\hline & $\mathrm{Na}^{+}$ & 4.95 & -0.15 & $\mathrm{~b}$ & 5.01 & & $\mathrm{~ns}$ & 1.78 & & ns & 6.43 & & ns \\
\hline & $\mathrm{K}^{+}$ & 0.58 & & ns & 0.28 & & ns & 0.15 & -0.02 & $\mathrm{a}$ & 0.47 & & ns \\
\hline & $\mathrm{Ca}^{2+}$ & 0.30 & & $\mathrm{~ns}$ & 0.13 & -0.01 & $\mathrm{c}$ & 0.26 & -0.01 & $\mathrm{c}$ & 4.18 & & ns \\
\hline & $\mathrm{Mg}^{2+}$ & 0.40 & -0.02 & $\mathrm{~b}$ & 0.37 & -0.01 & $\mathrm{~b}$ & 0.21 & 0.00 & $\mathrm{c}$ & 1.34 & & ns \\
\hline & $\mathrm{Fe}$ & 0.44 & & ns & 0.01 & 0.00 & $\mathrm{c}$ & 0.01 & 0.00 & $\mathrm{c}$ & 0.16 & & ns \\
\hline & $\mathrm{Al}$ & 0.61 & -0.02 & $\mathrm{~b}$ & 0.71 & -0.04 & a & 0.01 & 0.00 & $\mathrm{~b}$ & 0.08 & & ns \\
\hline & $\mathrm{NO}_{3}^{-}-\mathrm{N}$ & 0.03 & & ns & 0.02 & & ns & 0.38 & & ns & 0.13 & 0.01 & $\mathrm{~b}$ \\
\hline & $\mathrm{Cl}^{-}$ & 6.79 & -0.20 & $\mathrm{~b}$ & 7.49 & -0.22 & $\mathrm{c}$ & 2.7 & -0.05 & $\mathrm{c}$ & 7.34 & -0.15 & $\mathrm{~b}$ \\
\hline & $\mathrm{SO}_{4}^{2-}-\mathrm{S}$ & 1.13 & -0.09 & $\mathrm{a}$ & 1.7 & -0.07 & a & 0.68 & -0.03 & $\mathrm{~b}$ & 1.77 & -0.02 & $\mathrm{~b}$ \\
\hline & DOC & 18.04 & 0.54 & $\mathrm{c}$ & 2.68 & 0.16 & $\mathrm{~b}$ & 1.56 & & ns & 5.22 & & ns \\
\hline \multirow[t]{11}{*}{ SH } & $\mathrm{H}^{+} \mu \mathrm{M}$ & 65.05 & & ns & 18.95 & -1.14 & $\mathrm{~b}$ & 12.59 & & ns & 0.04 & 0.00 & $\mathrm{~b}$ \\
\hline & $\mathrm{Na}^{+}$ & 4.53 & -0.18 & $\mathrm{c}$ & 4.6 & -0.18 & b & 1.53 & & ns & 7.6 & & ns \\
\hline & $\mathrm{K}^{+}$ & 0.85 & -0.07 & $\mathrm{~b}$ & 0.37 & -0.06 & $\mathrm{a}$ & 0.14 & -0.02 & $\mathrm{~b}$ & 0.73 & -0.01 & $\mathrm{~b}$ \\
\hline & $\mathrm{Ca}^{2+}$ & 0.79 & -0.04 & $\mathrm{c}$ & 0.61 & -0.04 & b & 0.25 & -0.01 & $\mathrm{c}$ & 10.97 & & ns \\
\hline & $\mathrm{Mg}^{2+}$ & 0.57 & -0.03 & $\mathrm{~b}$ & 0.48 & -0.02 & $\mathrm{~b}$ & 0.18 & & ns & 3.83 & & $\mathrm{~ns}$ \\
\hline & $\mathrm{Fe}$ & 0.17 & & ns & 0.07 & & ns & 0 & 0.00 & $\mathrm{c}$ & 0 & & ns \\
\hline & $\mathrm{Al}$ & 0.75 & -0.02 & $\mathrm{~b}$ & 1.1 & & $\mathrm{a}$ & 0.01 & 0.00 & $\mathrm{~b}$ & 0.02 & & ns \\
\hline & $\mathrm{NO}_{3}^{-}-\mathrm{N}$ & 0.05 & & ns & 0.04 & & ns & 0.31 & -0.01 & $\mathrm{~b}$ & 0.2 & 0.00 & $\mathrm{c}$ \\
\hline & $\mathrm{Cl}^{-}$ & 6.63 & -0.40 & $\mathrm{~b}$ & 6.74 & -0.40 & $\mathrm{c}$ & 2.26 & -0.07 & $\mathrm{~b}$ & 7.92 & -0.16 & $\mathrm{a}$ \\
\hline & $\mathrm{SO}_{4}^{2-}-\mathrm{S}$ & 1.21 & -0.11 & $\mathrm{~b}$ & 1.37 & -0.12 & a & 0.51 & -0.03 & $\mathrm{a}$ & 2.34 & -0.02 & $\mathrm{~b}$ \\
\hline & DOC & 17.44 & & ns & 10.82 & -0.22 & $\mathrm{c}$ & 1.68 & & ns & 1.6 & & ns \\
\hline \multirow[t]{11}{*}{$\mathrm{MH}$} & $\mathrm{H}^{+} \mu \mathrm{M}$ & 62.94 & -3.15 & $\mathrm{a}$ & 29.93 & -1.20 & $\mathrm{a}$ & 9.89 & -0.99 & $\mathrm{a}$ & 0.19 & -0.03 & $\mathrm{c}$ \\
\hline & $\mathrm{Na}^{+}$ & 2.4 & -0.05 & $\mathrm{c}$ & 2.14 & & ns & 0.64 & & ns & 2.76 & & ns \\
\hline & $\mathrm{K}^{+}$ & 0.04 & & ns & 0.02 & & ns & 0.11 & & ns & 0.31 & & $\mathrm{~ns}$ \\
\hline & $\mathrm{Ca}^{2+}$ & 0.37 & -0.01 & $\mathrm{~b}$ & 0.62 & -0.01 & b & 0.19 & & ns & 9.74 & 0.10 & $\mathrm{~b}$ \\
\hline & $\mathrm{Mg}^{2+}$ & 0.2 & -0.01 & $\mathrm{~b}$ & 0.47 & -0.01 & $\mathrm{a}$ & 0.09 & & ns & 0.83 & & $\mathrm{~ns}$ \\
\hline & $\mathrm{Fe}$ & 0.16 & & $\mathrm{~b}$ & 0.22 & -0.01 & $\mathrm{a}$ & 0.01 & & ns & 0.33 & & ns \\
\hline & $\mathrm{Al}$ & 0.07 & & ns & 0.03 & & ns & 0 & & ns & 0.05 & & ns \\
\hline & $\mathrm{NO}_{3}^{-}-\mathrm{N}$ & 0.01 & & $\mathrm{~ns}$ & 0.01 & & $\mathrm{~ns}$ & 0.22 & 0.00 & $\mathrm{c}$ & 0.1 & -0.01 & $\mathrm{~b}$ \\
\hline & $\mathrm{Cl}^{-}$ & 3.01 & -0.09 & $\mathrm{~b}$ & 3.68 & -0.07 & $\mathrm{a}$ & 1.1 & & ns & 4 & -0.07 & $\mathrm{c}$ \\
\hline & $\mathrm{SO}_{4}^{2-}-\mathrm{S}$ & 0.1 & & $\mathrm{~ns}$ & 0.02 & & $\mathrm{~ns}$ & 0.56 & -0.02 & $\mathrm{c}$ & 1.19 & -0.04 & $\mathrm{c}$ \\
\hline & DOC & 22.21 & & ns & 17.05 & & $\mathrm{~ns}$ & 0.85 & & ns & 8.03 & & ns \\
\hline
\end{tabular}

Significance levels: ${ }^{\mathrm{a}} p \leq 0.001 ;{ }^{\mathrm{b}} p \leq 0.01 ;{ }^{\mathrm{c}} p \leq 0.05{ }^{1}$ No significant concentration trend until covariate was included.

\subsection{Climatic factors}

Mann-Kendall analyses of soil temperatures showed a significant increase at $\mathrm{GS}$ of $0.06^{\circ} \mathrm{C}_{\text {year }}^{-1}(p=0.02)$, but no significant change at $\mathrm{SH}(p=0.2)$ or $\mathrm{MH}(p=0.7)$. There were no significant Mann-Kendall trends in stream daily runoff at GS, SH, or MH ( $p=1.0,0.4$ and 0.6 , respectively). At GS there were weakly significant relationships between annual mean DOC concentrations in soil $\mathrm{O}$ and $\mathrm{B}$ horizons and 10 cm depth soil temperature (Fig. 4; 1993-2007, square symbols).

\subsection{Geochemical modelling}

Modelling results in this section relate to two terms describing the charge on the organic matter. Firstly, $\mathrm{Z}^{-}$ represents the charge on a unit mass of carbon, which relates to charge density as a control on solubility. Secondly, the term DOC. $\mathrm{Z}^{-}$represents the charge density multiplied by the concentration of DOC in solution, which may then be compared to other components of the solution charge to see the proportional charge contribution of the solubilised DOC. It should be remembered that the charge on the DOC 
(a)
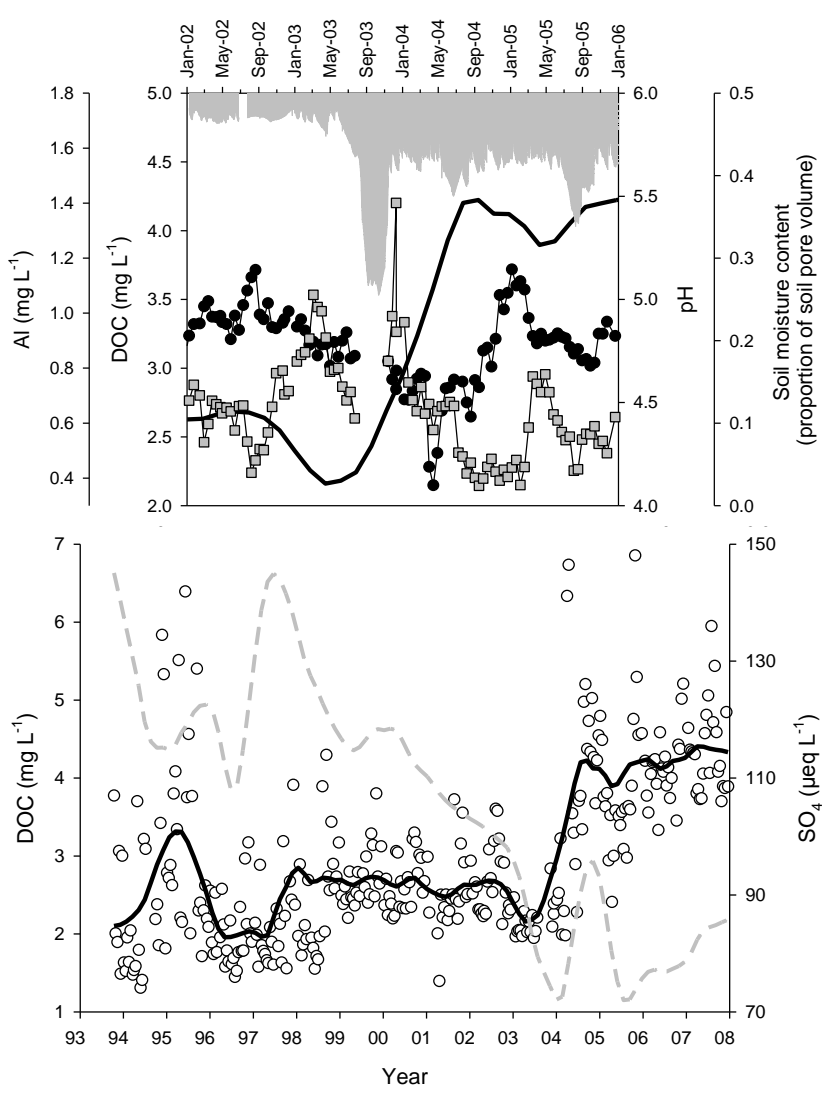

(b)

Fig. 2. Details of chemical changes in the podzol Bs horizon at Glensaugh. (a) details the period during the "step-change" in DOC concentration, with individual sample data for soil solution $\mathrm{Al}$ (grey squares), $\mathrm{pH}$ (black circles), soil moisture (grey area) and the Lowess-smoothed DOC trend (black line). This is set against (b) the background soil DOC trend (open circles plus solid line for Lowesssmoothed trend) and $\mathrm{SO}_{4}^{2-}$ Lowess-smoothed trend (dashed grey line).

is negative and hence a greater charge is denoted by larger negative numbers and increasing charge by a value becoming more negative over time.

Generally mean values for $\mathrm{Z}^{-}$were less negative (ie had less charge per unit mass of $C$ ) for stream waters $(-5.2$ and -5.0 meq $\mathrm{gC}^{-1}$ at $\mathrm{GS}$ and $\mathrm{SH}$ ) than deep soil solutions $\left(-4.2\right.$ meq gC $^{-1}$ at both sites) and shallow soil solutions $\left(-3.3\right.$ and -3.5 meq $\mathrm{gC}^{-1}$ at $\mathrm{GS}$ and $\left.\mathrm{SH}\right)$. When significant trends in $\mathrm{Z}^{-}$were examined they were opposite to trends in DOC concentrations (compare Tables 3 and 4). GS shallow DOC became less negatively charged (i.e. a positive trend of +0.03 meq gC $^{-1}$ year $\left.^{-1} ; p<0.01\right)$ whereas DOC concentrations increased. Conversely, negative charge increased at SH for deep soil waters $\left(-0.02\right.$ meq $\mathrm{gC}^{-1}$ year $\left.^{-1} ; p<0.01\right)$ and stream waters $\left(-0.005\right.$ meq gC $\left.\mathrm{gear}^{-1} ; p<0.01\right)$, whereas soil DOC concentrations decreased and showed no change for the stream. This was counter-intuitive to the idea that DOC solubility is proportional to charge density.

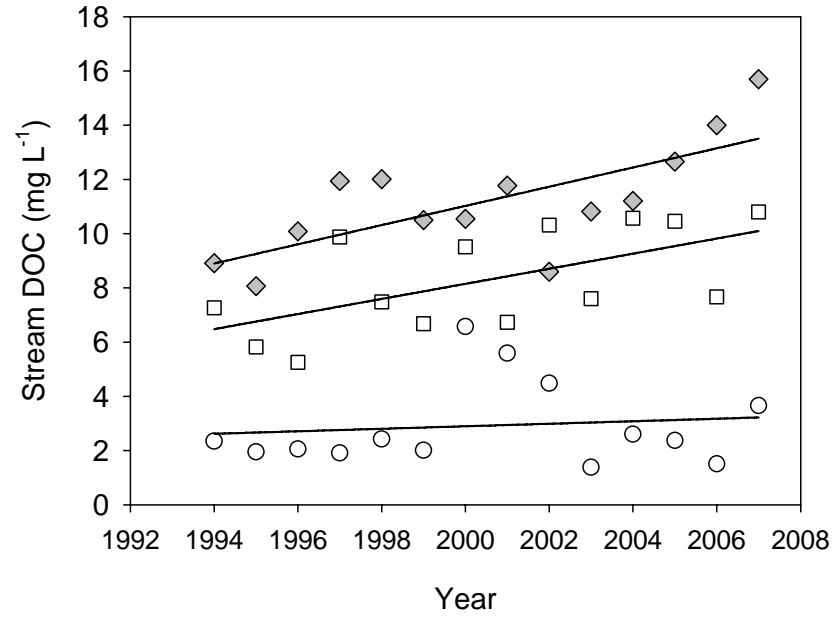

\begin{tabular}{|c|c|c|c|}
\hline & $\begin{array}{l}\text { Gradient } \\
\left(\text { mgC L }^{-1} \text { year }^{-1}\right)\end{array}$ & $\mathrm{R}^{2}$ & $p$ \\
\hline GS $\square$ & 0.28 & 0.37 & 0.02 \\
\hline SH O & 0.05 & 0.02 & 0.7 \\
\hline $\mathrm{MH} \diamond$ & 0.35 & 0.51 & 0.004 \\
\hline
\end{tabular}

Fig. 3. Trends in streamwater annual flow-weighted mean concentrations of DOC during the study period for the three sites Glensaugh (GS), Sourhope (SH) and Moorhouse (MH).

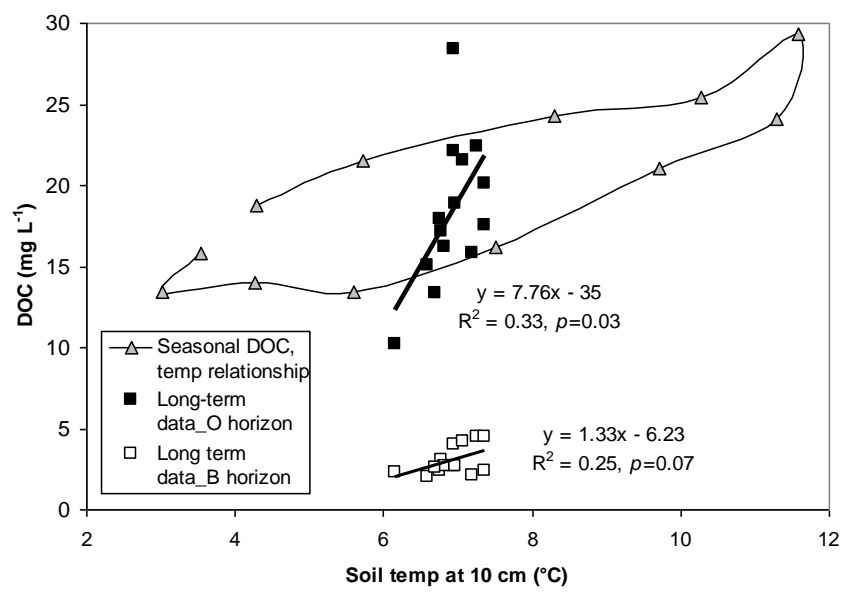

Fig. 4. Relationships for the GS Podzol between (i) annual mean soil solution DOC concentrations for $\mathrm{O}$ and $\mathrm{B}$ horizons and $10 \mathrm{~cm}$ depth soil temperature and (ii) mean monthly O horizon DOC and soil temperature also showing the direction of the hysteresis. 
Table 4. Median and temporal trends (ordinary Mann-Kendall tests for monotonic trends) for modelled solute parameters for ECN soil solutions (fortnightly data). Trends represent the annual change slope for significant temporal trends (in brackets).

\begin{tabular}{|c|c|c|c|c|c|c|c|c|c|c|c|}
\hline & $\mathrm{nm} B C$ & \multicolumn{2}{|c|}{$\mathrm{nmSO}_{4}^{2-}$} & & I & \multicolumn{2}{|c|}{$\mathrm{Z}^{-}$} & \multicolumn{2}{|c|}{ DOC.Z $Z^{-}$} & \multicolumn{2}{|c|}{$\mathrm{Al}_{\text {inorg }}$} \\
\hline $\begin{array}{l}\text { Glensaugh } \\
\text { Soii }\end{array}$ & 75 & 50 & $\left(-59^{a}\right)$ & 378 & $\left(-17^{\mathrm{a}}\right)$ & -33 & $\left(+0,03^{b}\right)$ & & $\left(+10^{\mathrm{c}}\right)$ & & $\left(-055^{a}\right.$ \\
\hline $\begin{array}{l}\text { Soil deep } \\
\text { Sourhope }\end{array}$ & 28 & 85 & $\left(-4.1^{b}\right)$ & 434 & $\left(-15^{\mathrm{a}}\right)$ & -4.2 & & 11.2 & $\left(+0.6^{\mathrm{b}}\right)$ & 22.5 & $\left(-1.6^{\mathrm{a}}\right)$ \\
\hline Soil shallow & 83 & 49 & $\left(-7.2^{b}\right)$ & 424 & $\left(-25^{\mathrm{b}}\right)$ & -3.5 & & 59.8 & & 6.7 & $\left(-1.0^{b}\right)$ \\
\hline $\begin{array}{l}\text { Soil deep } \\
\text { Moor House }\end{array}$ & 81 & 73 & $\left(-7.2^{\mathrm{a}}\right)$ & 441 & $\left(-30^{\mathrm{b}}\right)$ & -4.2 & $\left(-0.02^{b}\right)$ & 45.5 & $\left(-0.6^{\mathrm{c}}\right)$ & 25.7 & $\left(-2.8^{\mathrm{a}}\right)$ \\
\hline Soil shallow* & 42 & -3 & 143 & $\left(-5^{\mathrm{a}}\right)$ & -2.4 & $\left(+0.02^{c}\right)$ & 54.1 & 0.001 & $\left(-0.0002^{\mathrm{a}}\right)$ & & \\
\hline
\end{tabular}

Significance levels: ${ }^{\mathrm{a}} p<0.001 ;{ }^{\mathrm{b}} p<0.01 ;{ }^{\mathrm{c}} p<0.05 . \mathrm{nmBC}\left(\mu \mathrm{eqL} \mathrm{L}^{-1}\right)=$ non-marine base cations $\mathrm{nmSO} \mathrm{S}_{4}^{2-}\left(\mu \mathrm{eqL} \mathrm{L}^{-1}\right)=$ non-marine $\mathrm{SO}_{4} \mathrm{I}\left(\mu \mathrm{eq} \mathrm{L}^{-1}\right)=\mathrm{Model}$ calculated ionic strength Z- (meq g carbon ${ }^{-1}$ ) = Model calculated charge on fulvic acid DOC.Z $\left(\mu \mathrm{eq} \mathrm{L} \mathrm{L}^{-1}\right)=$ the $\mathrm{kg} \mathrm{L}^{-1}$ concentration of DOC multiplied by the charge on the organic molecule. $\mathrm{Al}_{\text {inorg }}\left(\mu \mathrm{eq} \mathrm{L}^{-1}\right)=$ the sum of mol $\mathrm{L}^{-1}$ multiplied by charge for dissolved $\mathrm{Al}$ species $\mathrm{Al}^{3+}, \mathrm{Al}(\mathrm{OH})^{2+}, \mathrm{Al}\left(\mathrm{SO}_{4}\right)^{+}$. *Note: Modelling was not performed for Moor House deep soil since data for reduced species of $\mathrm{S}$ and $\mathrm{N}$ were not available and ion balances could not be achieved.

Evans et al. (2008) explored the premises that (i) anion charge due to acidifying sulphate deposition suppresses DOC charge, and conversely (ii) declining acid deposition means DOC solubility is no longer suppressed and charge associated with DOC makes increasing contribution to anion sums. In this study the modelling term DOC. $Z^{-}$shows this charge associated with solubilised DOC. The trends in DOC. $Z^{-}$ were of the same direction as in DOC concentration (Tables 3 and 4). We evaluated the changing contributions over time of DOC. $Z^{-}$to anion charge associated with the pollutant anion ${ }_{\mathrm{nm}} \mathrm{SO}_{4}^{2-}$ over time in terms of the ratios annual mean DOC.Z $\mathrm{Z}^{-} / \mathrm{nmSO}_{4}^{2-}$ for soil solution concentrations (as eq $\mathrm{L}^{-1}$; Fig. 5). Although subsoil DOC concentrations increased at GS but decreased at $\mathrm{SH}$ both showed a rising contribution of DOC. $Z^{-}$compared to $\mathrm{nm}_{\mathrm{SO}}^{2-}$ as time progressed and DOC. $Z^{-}$increased as a proportion of the anion charge.

\subsection{Multiple regression analysis}

Using linear multiple regression modelling of annual medians none of the models could explain $>60 \%$ of the annual DOC concentration variance (Table 5). For soil solutions rain sulphate concentration was the dominant significant factor and where significant was negatively related to DOC concentration (except in the Moor House deep peat). Soil temperature was a weakly significant explanatory variable for the GS surface soil only. The positive influence of inter-annual rainfall variability on stream DOC concentrations shows increased flushing of soil solubilized DOC in wetter years. There was no evidence of enhanced prediction by combining variables.

\section{Discussion}

\subsection{Soil DOC responses to environmental change factors}

The divergent DOC concentration trends for these three soils at the ECN sites contrasts to a dominance of decreasing DOC concentration trends in the compiled soil solution literature (Table 1). The only previous observation of strongly increasing soil solution DOC, as found for the GS podzol, was Hruška et al. (2009). These authors reported 250-400\% increases in surface horizons of two freely-drained organomineral soils in previously heavily S-polluted forests in the Czech Republic. The differences in decadal soil solution DOC trends may result from the combination of external drivers and soil properties governing the response to these drivers. We consider what evidence our study provides for (i) the extent of change, (ii) resulting pressure and (iii) impact of three key drivers in turn, namely, deposition, temperature and soil water conditions.

\subsubsection{Acid deposition}

Sulphate, $\mathrm{pH}$ trends (Fig. 1; Table 3) and documented acid $\mathrm{SO}_{4}^{2-}$ loads suggest that the three ECN sites share a common recovery from acidification. Declines in deposition $\mathrm{SO}_{4}$ concentrations were comparable between sites (MK trends -1.1 to $-1.9 \mu \mathrm{eq} \mathrm{L}^{-1} \mathrm{year}^{-1}$ ) and of the same magnitude as documented decreases in the UK (Fowler et al., 2005) and eastern United States (Driscoll et al., 2001). Previous studies have shown that peak deposition $\mathrm{SO}_{4}^{2-}$ loads at these sites ranged between $1 \mathrm{keq} \mathrm{ha}^{-1} \mathrm{yr}^{-1}$ (GS and SH) to $2 \mathrm{keq} \mathrm{ha}^{-1} \mathrm{yr}^{-1}(\mathrm{MH})$ in the 1980 s and exceeded the sites' Critical Loads of Acidity (a threshold load prior to ecosystem damage occurring) of $0.2-0.5 \mathrm{keqH}^{+} \mathrm{ha}^{-1} \mathrm{yr}^{-1}$ (CLAG, 2004). 
Table 5. Multiple regression modelling of changes in DOC concentrations $(n=14)$. Predictors are given along the top column. For each model the amount of variance explained is given as $\%$. Significance $(p)$ values of model terms are in italics, with the coefficients of terms for significant models in parentheses (and in bold).

\begin{tabular}{|c|c|c|c|c|c|c|c|}
\hline & & $\begin{array}{l}\text { Rain } \mathrm{SO}_{4}^{2-} \\
\left(\mu \mathrm{eq} \mathrm{L}^{-1}\right)\end{array}$ & $\begin{array}{l}\text { Soil temp } \\
\left({ }^{\circ} \mathrm{C}\right)\end{array}$ & $\begin{array}{l}\text { Rain } \\
(\mathrm{mm})\end{array}$ & $\begin{array}{l}\mathrm{SO}_{4}^{2-} \times \\
\text { Temp }\end{array}$ & $\mathrm{SO}_{4}^{2-} \times$ Rain & $\mathrm{SO}_{4}^{2-} \times$ Temp $\times$ Rain \\
\hline GS & $\begin{array}{l}\text { Soil } \\
\text { surface } \\
\text { Soil } \\
\text { deep } \\
\text { Stream }\end{array}$ & $\begin{array}{l}41 \% \\
0.01(-0.20) \\
43 \% \\
0.01(-0.04) \\
40 \% \\
0.02(-0.08)\end{array}$ & $\begin{array}{l}31 \% \\
0.03(+7.8) \\
26 \% \\
0.07 \\
29 \% \\
0.05(+3.1)\end{array}$ & $\begin{array}{l}19 \% \\
0.13 \\
10 \% \\
0.27 \\
\mathbf{3 1 \%} \\
\mathbf{0 . 0 4}(+\mathbf{0 . 0 0 5})\end{array}$ & $\begin{array}{l}45 \% \\
0.15,0.42 \\
44 \% \\
0.08,0.73 \\
42 \% \\
0.13,0.55\end{array}$ & $\begin{array}{l}45 \% \\
0.04,0.39 \\
44 \% \\
0.03,0.76 \\
52 \% \\
0.05,0.13\end{array}$ & $\begin{array}{l}50 \% \\
0.30,0.37,0.34 \\
45 \% \\
0.12,0.72,0.75 \\
56 \% \\
0.32,0.41,0.12\end{array}$ \\
\hline SH & $\begin{array}{l}\text { Soil } \\
\text { surface } \\
\text { Soil } \\
\text { deep } \\
\text { Stream }\end{array}$ & $\begin{array}{l}\mathbf{5 1 \%} \\
\mathbf{0 . 0 0 4}(-\mathbf{0 . 2 4}) \\
1 \% \\
0.78 \\
4 \% \\
0.50\end{array}$ & $\begin{array}{l}4 \% \\
0.50 \\
10 \% \\
0.27 \\
9 \% \\
0.31\end{array}$ & $\begin{array}{l}14 \% \\
0.20 \\
2 \% \\
0.68 \\
\mathbf{2 8 \%} \\
\mathbf{0 . 0 5}(\mathbf{+ 0 . 0 0 5 )}\end{array}$ & $\begin{array}{l}56 \% \\
0.004,0.29 \\
11 \% \\
0.72,0.28 \\
27 \% \\
0.13,0.09\end{array}$ & $\begin{array}{l}56 \% \\
0.008,0.30 \\
3 \% \\
0.71,0.64 \\
29 \% \\
0.74,0.08\end{array}$ & $\begin{array}{l}57 \% \\
0.013,0.46,0.41 \\
12 \% \\
0.82,0.67,0.56 \\
34 \% \\
0.32,0.17,0.14\end{array}$ \\
\hline $\begin{array}{l}\mathrm{M} \\
\mathrm{H}\end{array}$ & $\begin{array}{l}\text { Soil } \\
\text { surface } \\
\text { Soil } \\
\text { deep } \\
\text { Stream }\end{array}$ & $\begin{array}{l}13 \% \\
0.20 \\
\mathbf{2 9} \% \\
\mathbf{0 . 0 5}(+\mathbf{0 . 0 3}) \\
2 \% \\
0.60\end{array}$ & $\begin{array}{l}9 \% \\
0.30 \\
1 \% \\
0.74 \\
14 \% \\
0.19\end{array}$ & $\begin{array}{l}20 \% \\
0.11 \\
17 \% \\
0.15 \\
5 \% \\
0.43\end{array}$ & $\begin{array}{l}24 \% \\
0.16,0.23 \\
31 \% \\
0.05,0.56 \\
17 \% \\
0.50,0.19\end{array}$ & $\begin{array}{l}32 \% \\
0.18,0.11 \\
45 \% \\
0.04,0.10 \\
8 \% \\
0.61,0.45\end{array}$ & $\begin{array}{l}38 \% \\
0.16,0.39,0.18 \\
45 \% \\
0.05,0.84,0.14 \\
19 \% \\
0.53,0.26,0.65\end{array}$ \\
\hline
\end{tabular}

Simple competitive sorption theory suggests that a declining presence of sulphate anions would lead to stronger DOC binding to soils (Wu et al., 2010). This would cause the opposite effect to the increasing DOC concentrations observed at GS due to the prediction of stronger sorption of DOC to soil surfaces over the time of declining sulphate deposition. Geochemical modelling can be used to explain such apparent complex system behaviour against such simplistic principles (Meeussen et al., 1999). The success of such modelling approaches to explain this complex behaviour relies on their ability to integrate geochemical factors of $\mathrm{pH}$, ionic strength, $\mathrm{SO}_{4}^{2-}$ concentrations and organic matter complexation with $\mathrm{Al}$ as factors governing the charge on the DOC. Overcoming the constraints of this charge on the DOC is a primary factor in initialising or maintaining the DOC solubility (Lumsdon et al., 2005; Löfgren et al., 2010).

Our modelling of the ECN soil waters showed counterintuitive changes in DOC charge (the charge density parameter $\mathrm{Z}^{-}$, Table 4), namely that rising DOC concentrations in the GS subsoil were associated with a declining trend in DOC charge density, but decreasing DOC in the SH subsoil accompanied an increasing DOC charge density. This suggests that just considering the charge density alone is insufficient to explain solubility, since GS subsoil DOC increased over time despite decreasing charge density and the opposite for the SH subsoil. Previously observed increases in the negative charge of freshwater DOC in Norway of -2 to -5 meq $\mathrm{gC}^{-1}$ during $1985-2003$ have been argued as a mechanistic connection between rising DOC and declining pollutant $\mathrm{SO}_{4}$ deposition (de Wit et al., 2007). However, in soils the presence of $\mathrm{Al}$ may exert a substantial influence on the DOC charge through complexation and this factor has been recently explored by Löfgren et al. (2010). Enhanced Al binding with rising $\mathrm{pH}$ can counter an increasing negative charge density on the DOC that would occur in response to proton reduction with declining acid deposition. Given that the common declines in ionic strength (mainly attributed to $\mathrm{SO}_{4}^{2-}$ ), would decrease overall suppression of anion charge on the DOC, the remaining explanation for differing trends in $\mathrm{Z}^{-}$is Al complexation. Löfgren et al. (2010) previously used similar geochemical modelling to show that recovery from acidification could trigger positive, negative or no trends in soil solution DOC according to $\mathrm{pH}$, ionic strength and soil Al. Löfgren et al. (2010) concluded Al complexation was the common solubility control across soils of differing DOC trend directions. Hence, the geochemical modelling approach highlights the complexity of the sorption process affecting DOC and the key influences of competitive processes involving charged solution species, especially protons, $\mathrm{Al}$ and $\mathrm{SO}^{2-}$, on changing DOC solubility. This indicates that simple theories involving isolated chemical processes are unlikely to adequately explain changing DOC concentrations, and this becomes more pertinent when geochemical and biological effects are considered together. 
(a) Surface soil solutions

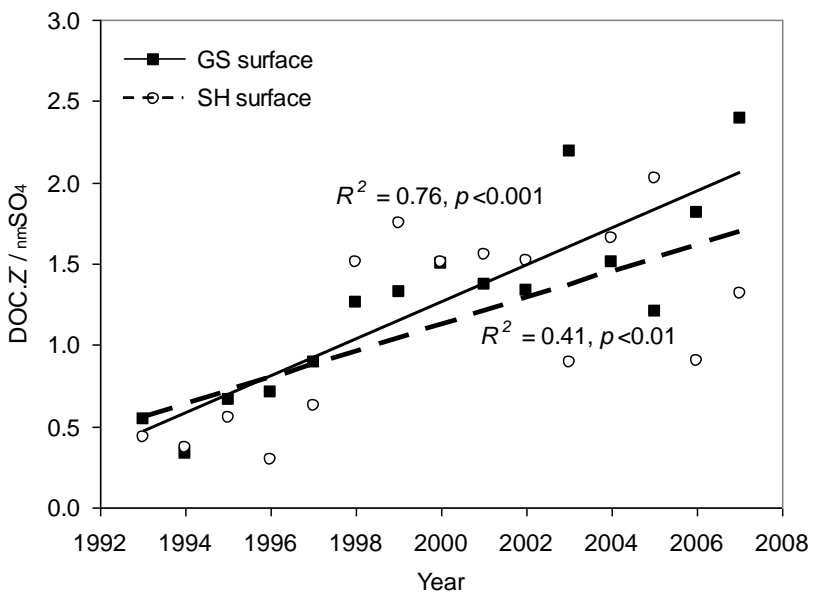

(b) Deep soil solutions

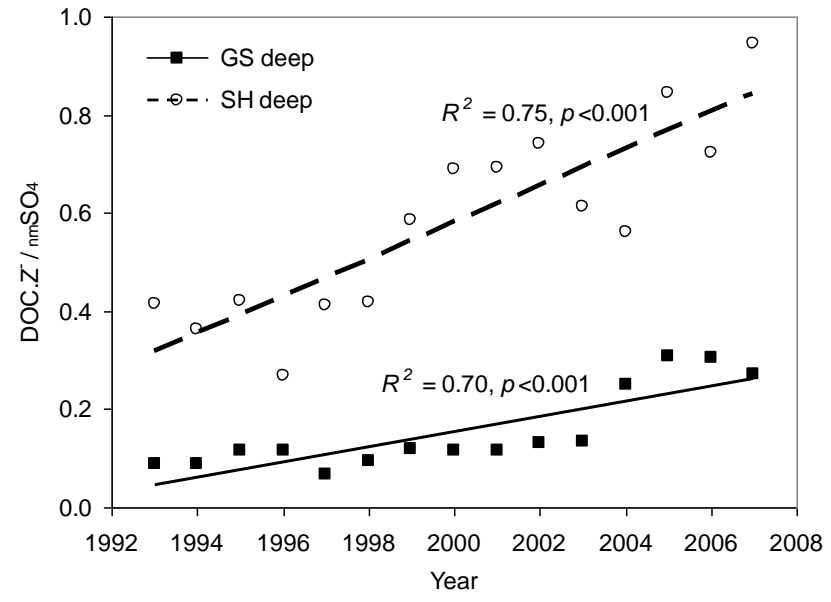

Fig. 5. The ratio of annual mean DOC. $Z^{-}\left(\right.$eq $\left.\mathrm{L}^{-1}\right)$ to annual mean $\mathrm{nm}_{\mathrm{SO}}^{2-}\left(\mathrm{eq}^{-1}\right)$ for (a) surface and (b) deep soil solutions at Glensaugh and Sourhope showing commonality in the increasing contribution of DOC to the non-marine component of the anion charge during declining pollutant sulphate concentrations.

\subsubsection{Temperature change}

Only the GS surface soil showed a significant soil warming trend in hourly data (overall $0.9^{\circ} \mathrm{C}$ ) at any site (Table 2). This precluded us from testing the effects and interactions of temperature and other drivers between soils. Although temperature is an important control on organic matter decomposition this limited temperature rise at GS was unlikely to by itself account for the substantial DOC rise. Figure 4 suggests a weak relationship between O horizon DOC and soil temperature at GS was considerably steeper than the gradient of the seasonal response of DOC to temperature. We previously observed under laboratory controlled conditions of stable moisture and light that respiration for the GS surface soil responded positively to temperature, but DOC concentration increases were small (Stutter et al., 2007). Our simple regression modelling of annual means (thereby removing autocorrelations due to strong seasonality e.g. Clark et al., 2010) suggested that temperature was a weak predictor of soil solution DOC, similar to the regression modelling of temperature for lake DOC by Evans et al. (2006).

\subsubsection{Inter-relationships between driving processes}

The ability of the relatively small rise in temperature at GS to stimulate a large increase in DOC may be related to the synergistic action of temperature with both geochemical solubility controls and soil water status. Studies on the interrelationship of temperature and water table draw down suggest that decomposition rates are stimulated to a greater degree by temperature increases in drier, than wetter soil profiles (Worrall et al., 2004b; Clark et al., 2009). The process for this may relate to $\mathrm{O}_{2}$ availability for respiration, or the increased activity of certain enzymes facilitating breakdown of phenolic structures in humic material (Freeman et al., 2001).

Temperature and geochemistry also affect DOC simultaneously rather than independently (Lumsdon et al., 2005; Clark et al., 2010). Chemical solubility of DOC requires prior biological decomposition of soil organic matter, but also that certain biological systems favour DOC once solubilized. The biologically-mediated decomposition of soil organic matter yields "potentially-soluble" DOC (Tipping, 2002), which must then overcome chemical constraints of $\mathrm{pH}$, ionic strength and metal complexation to enable release from soil surfaces into pore waters.

In summary these chemical-biological-physical interactions suggest why the DOC response of the GS podzol was unique to these three soils. Thus freely-drained organomineral soils (as typified by the GS Podzol) have inherent susceptibility to: (i) chemical factors of DOC solubility due to the reactive Fe complexes, and (ii) decomposition factors since the lower thermal mass means the soil reacts more to air temperature changes and solar radiation. Such complex interactions between acidification, temperature and hydrology have contributed to the inability of a decade of studies in ascribing a dominant influence of one set of processes more than another on DOC release. Geochemical processes, driven by acidification recovery, and biological-decomposition processes, driven by climate change, were formerly seen as somewhat competing hypotheses for soil $\mathrm{C}$ change. This was, in part, due to acidification reversal being seen as a "recovery" to previous pre-industrial conditions and climate change a continuing perturbation (Evans et al., 2006). However, the review of Clark et al. (2010) has shown that many perceived differences could be attributed to the complexity of unravelling trend and process data across different temporal and spatial scales. 


\subsection{How do soil property differences govern the response of different soils to environmental change?}

Many soil properties that affect DOC release, including organic matter accumulation, composition and reactivity, soil chemistry, redox and vegetation, are strongly influenced by drainage status (Kalbitz et al., 2000). Hence soil drainage differences strongly influence the magnitude of DOC release in response to other environmental change factors. Differences between site vegetation (related strongly to soil hydrology) would affect the composition and reactivity of the soil C formed (Kalbitz et al., 2000). The wetter soils at SH supported grassland, whereas the MH and GS sites were heather dominated moorland. The MH site is also at higher altitude, cooler and with approximately double the annual rainfall of either GS or SH (Table 2). The effects of vegetation cover on the nature of the soil DOC are not well understood. It is likely that Calluna moorland, acid grassland and sphagnumdominated bog produce soil organic matter of differing phenolic contents and hence hydrophobicity, causing differences in decomposition rates and in the charge required to overcome abiotic solubility constraints (Clark et al., 2010).

Peatlands have long been recognised as major contributors to DOC loads to rivers (Aitkenhead et al., 1999). Whilst the MH stream waters and soil have the greatest median DOC concentrations of these sites (Table 2), the concentrations do not show the long term increase of the humus iron Podzol site. The key difference in soil properties was that freelydraining conditions at GS have led to large concentrations of Fe sesquioxide complexes in the podzol subsoil (see oxalate extractable Fe contents; Table 2), which govern DOC and $\mathrm{SO}_{4}^{2-}$ sorption (Ussiri and Johnson, 2004). These amorphous hydrous ferric oxide coatings were tenfold more concentrated in the GS than SH subsoil (and generally thought negligible in peats). The GS Podzol, with high amorphous Fe content, would store considerably more sulphate during acid deposition loading. A corresponding longer desorption period (lag in sulphate recovery) for the GS than SH podzol means we are likely to be comparing the soils at different stages of the sulphate desorption "recovery". Therefore, the ECN monitoring may have missed a shorter, earlier period of DOC release in the SH and MH soils.

Sulphate desorption from the GS subsoil was not simply linear, but perturbed by physico-chemical "episodes" associated with soil moisture change. Evidence can be seen in the "step" increase in DOC concentrations after the 2003 drought (Fig. 2). The flush of $\mathrm{SO}_{4}^{2-}$ acidity (from stored $\mathrm{SO}_{4}^{2-}$ associated with the large sorption capacity) on rewetting may have leached out some complexing cations (e.g. Al) leading to the subsequent elevated state of DOC solubility. Climatic episodes associated with droughts are more commonly reported for wetland soils, including peatlands (Clark et al., 2005; Eimers et al., 2008; Laudon, 2008). At the extreme scale of wetness, the MH soil shows different dominant processes associated with hydrological and redox controls on peatland stored S. Droughts and lowering of the water table at MH in 1995 and 2003 led to short-term suppression of DOC concentrations (Fig. 1). These latter sulphate oxidation drought 'episodes' were reported by Clark et al. (2005) and used as the basis for earlier theories about suppression of DOC concentrations by acid deposition. In contrast the GS Podzol provides evidence for sustained DOC release following acidification episodes associated with drought. Eimers et al. (2008) showed relationships between DOC and $\mathrm{SO}_{4}$ concentrations in wetland soils in Canada that switched from positive to negative between seasons. Clark et al. (2010) therefore urged caution in interpreting these short-term (seasonal to inter-annual) $\mathrm{S}$ oxidation processes when considering sulphate as a long-term driver for DOC release. However, our understanding of sites, such as $\mathrm{MH}$, with variable redox states is limited by monitoring only oxidised chemical species. We would therefore urge that a more complete assessment of chemistry and redox be made for wetland soils.

\subsection{The implications of rising DOC release in podzols for landscape C stability}

If increasing soil DOC concentrations at GS are indicative of a wider extent of increase in podzol soils then this would have substantial implications for destabilisation of terrestrial organic carbon across UK, northern European and American moorlands where these Podzols dominate. Compared to the data summarised in Table 1 this is a new finding, since (i) most sites show decreasing DOC trends and (ii) forested ecosystems are dominantly represented. Soil carbon held in podzols has been previously poorly considered, despite being large. When soil bulk density is accounted for podzolic subsoils store equivalent $\mathrm{C}$ even to peats (Table 1). Freelydraining podzols in Scotland hold 5\% (350 Mt) of total soil organic carbon, compared with $0.3 \%$ in gleyed podzols and $65 \%$ in peat (Milne and Brown, 1997). Whilst the carbon in peats has previously received much wider attention, much of this may be inert due to oxygen and hydraulic constraints (Ingram, 1978). As anecdotal evidence, iron Podzol dominated catchments in NE Scotland have shown amongst the greatest streamwater DOC concentration increases in the UK (Worrall et al. 2004a). Globally, Podzols $\left(4.9 \times 10^{6} \mathrm{~km}^{2}\right)$ are more extensive than Histosols (peat; $3.2 \times 10^{6} \mathrm{~km}^{2}$ ) and global Podzol distribution (http://www.fao.org/ag/agl/agll/ wrb/wrbmaps/htm/domsoi.htm) maps closely with locations of reported surface water DOC concentration rises (Monteith et al., 2007). We hope this initial evidence will provoke a collation and assessment of global soil solution studies and debate on the role of mineral-organic soil complexes in explaining losses of soil carbon. 
Table 6. Summary of trends in DOC and potential explanatory variables across all sites. Arrows with symbols $\downarrow$, $\uparrow$ and $\leftrightarrow$ denote trends showing significant decrease, increase or no significant change, respectively.

\begin{tabular}{|c|c|c|c|c|c|c|c|c|}
\hline & & DOC & $\mathrm{pH}$ & $\mathrm{SO}_{4}^{2-}$ & $\begin{array}{l}\text { Ionic } \\
\text { strength }\end{array}$ & Z- & $\begin{array}{c}\text { DOC.Z- } \\
/ \\
\mathrm{nmSO}_{4}^{2-}\end{array}$ & Temp. \\
\hline \multirow[t]{3}{*}{ GS } & Surface & $\uparrow$ & $\leftrightarrow$ & $\downarrow$ & $\downarrow$ & $\uparrow^{*}$ & $\uparrow$ & $\uparrow$ \\
\hline & Deep & $\uparrow$ & $\uparrow$ & $\downarrow$ & $\downarrow$ & $\leftrightarrow$ & $\uparrow$ & nd \\
\hline & Stream & $\uparrow$ & $\uparrow$ & $\downarrow$ & nd & nd & nd & nd \\
\hline \multirow[t]{3}{*}{ SH } & Surface & $\leftrightarrow$ & $\leftrightarrow$ & $\downarrow$ & $\downarrow$ & $\leftrightarrow$ & $\uparrow$ & $\leftrightarrow$ \\
\hline & Deep & $\downarrow$ & $\uparrow$ & $\downarrow$ & $\downarrow$ & $\downarrow^{*}$ & $\uparrow$ & nd \\
\hline & Stream & $\leftrightarrow$ & $\uparrow$ & $\downarrow$ & nd & nd & nd & nd \\
\hline \multirow[t]{3}{*}{$\mathrm{MH}$} & Surface & $\leftrightarrow$ & $\uparrow$ & $\leftrightarrow$ & $\downarrow$ & $\uparrow^{*}$ & nd & $\leftrightarrow$ \\
\hline & Deep & $\leftrightarrow$ & $\uparrow$ & $\leftrightarrow$ & nd & nd & nd & nd \\
\hline & Stream & $\uparrow$ & $\leftrightarrow$ & $\downarrow$ & nd & nd & nd & nd \\
\hline
\end{tabular}

*For Z-, the charge on the DOC, an increasing trend indicates that the anionic charge becomes more positive (i.e. becoming less charged) and a decreasing trend indicates becoming more negatively charged.

\subsection{How to rationalise the heterogeneous DOC response of component soils with more consistent stream water trends at catchment scales?}

Strongly diverging DOC concentration trends for these three representative UK moorland soils contrast with the ubiquitous positive DOC concentration trends widely reported. In our study stream waters showed increasing annual flow weighted mean DOC commonly at all sites (Fig. 3, Table 2) and rainfall was a dominant predictor (Table 5). We suggest this as evidence that stream water DOC trends are dominantly controlled by catchment hydrology, as previously proposed (Tranvik and Jannsson, 2002; Hongve et al., 2004; Erlandsson et al., 2008). Ubiquitous hydrological changes between sites may therefore explain consistent patterns in stream DOC trends, when spatially-varying soil solution DOC trends are related to heterogeneous soil properties variably affecting DOC solubility. The availability of ECN data for only a single soil plot precludes an explanation of stream DOC response from the component soils that make up the whole catchment.

\subsection{Implications for soil carbon models}

In order to increase mechanistic understanding, make regional and future predictions of soil $\mathrm{C}$ losses model development needs to include (i) spatial representation of certain soils such as freely drained podzols susceptible to rising DOC solubility, (ii) incorporation of the key properties of these soils affecting sorption, such as Fe rich podzolic subsoils and (iii) the necessary biological and geochemical solubility controls acting with these soil properties. The implications of this study are important over a range of modelling scales. Firstly, at national to regional scales better recognition of the contributions of certain organo-mineral soils to changing DOC concentrations is needed. This may inform export coefficient type modelling of $\mathrm{C}$ losses and understanding regionally which soil $\mathrm{C}$ reserves are susceptible to loss and should be managed. At catchment scales soil heterogeneity across peats to organo-mineral soils of different drainage status should be considered. At pedon scales key properties such as the geochemistry of $\mathrm{Fe}$ and $\mathrm{Al}$ surface complexes and changes in water conditions need to be considered together, instead of the previously used simpler set of the properties used for modelling such as particle size and clay content.

A number of previous models based on organic matter turnover, for example RothC (Coleman and Jenkinson, 1999) and ECOSSE (Smith et al., 2007), do not consider the important pathway of $\mathrm{C}$ loss as DOC and focus on gaseous $\mathrm{C}$ losses. Our study suggests that soil DOC release is an important component of understanding and predicting $\mathrm{C}$ behaviour at landscape scales by determining the availability of this DOC for flushing to streams and as an intermediate step for respiration and direct $\mathrm{C}$ loss to the atmosphere. A number of catchment-based models have tackled DOC losses to aquatic systems. There are few examples consider in-soil processes. Amongst these are the models DyDOC (Michalzik et al., 2003), ORCHESTRA (Lumsdon et al., 2005) and INCA-C (Futter et al., 2007). This study will benefit the development of catchment to pedon scale models by highlighting key processes, providing a basis for, and provoking a wider use of, fundamental soil data to parameterise and calibrate these models. In addition, we have shown that certain organo-mineral soils are not likely to be in a steady state with respect to $\mathrm{C}$ solubility across decadal timescales, but also may be prone to certain "tipping points" which need model representation. 


\section{Supplementary material related to this article is available online at: http://www.biogeosciences.net/8/3661/2011/ bg-8-3661-2011-supplement.pdf.}

Acknowledgements. We thank the UK Environmental Change Network (www.ecn.ac.uk) for access to the sites' data. Also, we thank the Scottish Government Rural Environment Research and Analysis Directorate for funding this research and H. Watson for collating the Environmental Change Network data.

Edited by: J. Leifeld

\section{References}

http://www.ecn.ac.uk/sites.htm, Environmental Change Network, Site Information, last accessed: September 2009.

http://www.ecn.ac.uk/protocols/index.asp, Environmental Change Network, Protocols for freshwater and terrestrial sites, last accessed: September 2009.

http://www.fao.org/ag/agl/agll/wrb/wrbmaps/htm/domsoi.htm, Food and Agriculture Organization of the United Nations (F.A.O.) World Reference Base Dominant soil map, last accessed: November 2009.

Aitkenhead, J. A., Hope, D., and Billett, M. F: The relationship between dissolved organic carbon in stream water and soil organic carbon pools at different spatial scales, Hydrol. Process, 13, 1289-1302, 1999.

Batjes, N. H.: Total carbon and nitrogen in soils of the world, Eur. J. Soil Sci., 47, 151-163, 1996.

Buckingham, S., Tipping, E., and Hamilton-Taylor, J.: Concentrations and fluxes of dissolved organic carbon in UK topsoils, Sci. Total Environ., 407, 460-470, 2008.

CLAG: Critical Loads of Acidity in the UK. Critical Loads Advisory Group, Summary Report, Institute of Terrestrial Ecology, UK, 2004.

Clair, T. A., Dennis, T. F., Vet, R., and Laudon, H.: Long-term trends in catchment organic carbon and nitrogen exports from three acidified catchments in Nova Scotia, Canada. Biogeochem., 87, 83-97, 2008.

Clark, J. M., Chapman, P. J., Adamson, J. K., and Lane, S. N.: Influence of drought-induced acidification on the mobility of dissolved organic carbon in peat soils, Glob. Change Biol., 11, 791809, 2005.

Clark, J. M., Ashley, D., Wagner, D., Chapman, P. J., Lane, S. N., Evans, C. D., and Heathwaite, A. L.: Increased temperature sensitivity of net DOC production from ombrotrophic peat due to water table draw-down, Glob. Change Biol., 15, 794-807, 2009.

Clark, J. M., Bottrell, S. H., Evans, C. D., Monteith, D. T., Bartlett, R., Rose, R., Newton, R. J., and Chapman, P. J.: The importance of the relationship between scale and process in understanding long-term DOC dynamics, Sci. Total Environ., 408, 2768-2775, 2010.
Coleman, K. and Jenkinson, D. F.: ROTHC-26.3. A model for the turnover of carbon in soil, Report, Rothamsted Research, UK, http://www.rothamsted.bbsrc.ac.uk/aen/carbon/rothc.ht, 1999.

Dawson, J. J. C., Malcolm, I. A., Middlemass, S. J., Tetzlaff, D., and Soulsby, C.: Is the composition of dissolved organic carbon changing in acidic upland streams, Environ. Sci. Technol., 43, 7748-7753, 2009.

de Wit, H. A., Mulder, J., Nygaard, P. H., and Aamlid, D.: Testing the aluminium toxicity hypothesis: A field manipulation experiment in mature spruce forest in Norway, Water Air Soil Poll., 130, 995-1000, 2001.

de Wit, H. A., Mulder, J., Hindar, A., and Hole, L.: Long term increase in dissolved organic carbon in streamwaters in Norway is response to reduced acid deposition, Environ. Sci. Technol., 41, 7706-7713, 2007.

Driscoll, C. T., Lawrence, G. B., Bulger, A. J., Butler, T. J., Cronan, C. S., Eager, C., Lambert, K. F., Likens, G. E., Stoddard, J. L., and Weathers, K. C.: Acidic deposition in the northeastern United States: sources and inputs, ecosystem effects, and management strategies, BioScience, 51, 180-198, 2001.

Eimers, M. C., Watmough, S. A., Buttle, J. M., and Dillon, P. J.: Examination of the potential relationship between droughts, sulphate and dissolved organic carbon at a wetland-draining stream, Glob. Change Biol., 14, 938-948, 2008.

Erlandsson, M., Buffam, I., Folster, J., Laudon, H., Temnerud, J., Weyhenmeyer, G. A., and Bishop, K.: Thirty-five years of synchrony in the organic matter concentrations of Swedish rivers explained by variation in flow and sulphate, Glob. Change Biol., 14, 1191-1198, 2008.

Eswaran, H., van den Berg, E., and Reich, P.: Organic carbon in soils of the world, Soil Sci. Soc. Am. J., 57, 192-194, 1993.

Evans, C. D., Chapman, P. J., Clark, J. M., Monteith, D. T., and Cresser, M. S.: Alternative explanations for rising dissolved organic carbon export from organic soils, Glob. Change Biol., 12, 2044-2053, 2006.

Evans, C. D., Monteith, D. T., Reynolds, B., and Clark, J. M.: Buffering of recovery from acidification by organic acids, Sci. Total Environ., 404, 316-325, 2008.

Fowler, D., Smith, R. I., Muller, J. B. A., Hayman, G., and Vincent, K. J.: Changes in the atmospheric deposition of acidifying compounds in the UK between 1986 and 2001, Env. Pollut., 137, 15-25, 2005.

Futter, M. N., Butterfield, D., Cosby, B. J., Dillon, P. J., Wade, A. J., and Whitehead, P. G.: Modelling the mechanisms that control in-stream dissolved organic carbon dynamics in upland and forested catchments, Wat. Res. Res., 43, W02424, doi:10.1029/2006WR004960, 2007.

Freeman, C., Evans, C. D., Monteith, D. T., Reynolds, B., and Fenner, N.: Export of organic carbon from peat soils, Nature, 412, 785 pp., 2001.

Hirsch, R. M. and Slack, J. R.: A nonparametric trend test for seasonal data with serial dependence, Wat. Res. Res., 20, 727-732, 1984.

Hope, D., Billett, M. F., Milne, R., and Brown, T. A. W.: Exports of carbon in British rivers, Hydrol. Process, 11, 325-333, 1997.

Hongve, D., Riise, G., and Kristiansen, J. F.: Increased colour and organic acid concentrations from Norwegian forest lakes and drinking waters-a result of increased precipitation? Aquat. Sci., 66, 231-238, 2004. 
Hruška, J., Krám, P., McDowell, R. H., and Oulehle, F.: Increased dissolved organic carbon (DOC) in central European streams is driven by reductions in ionic strength rather than climate change or decreasing acidity, Environ. Sci. Technol., 43, 4320-4326, 2009.

Ingram, H. A. P.: Soil layers in mires: function and terminology, J. Soil Sci., 29, 224-227, 1978.

Kalbitz, K., Solinger, S., Park, J.-H., Michalzik, B., and Matzner, E.: Controls on the dynamics of dissolved organic matter in soils: a review, Soil Sci., 165, 277-304, 2000.

Kirschbaum, M. U. F.: The temperature dependence of soil organic matter decomposition, and the effect of global warming on soil organic C storage, Soil Biol. Biochem., 27, 753-760, 1995.

Knorr, W.: Long term sensitivity of soil carbon turnover to warming, Nature, 433, 298-301, 2005.

Laudon, H.: Recovery from episodic acidification delayed by drought and high sea salt deposition, Hydrol. Earth Syst. Sci., 12, 363-370, 2008, http://www.hydrol-earth-syst-sci.net/12/363/2008/.

Lawler, A. J. and Tipping, E.: Metals in deposition and surface water at two upland locations in northern England, Environ. Pollut., 121, 153-167, 2003.

Löfgren, S., Gustafsson, J. P., and Bringmark, L.: Decreasing DOC trends in soil solution along the hillslopes at two IM sites in southern Sweden - Geochemical modelling of organic matter solubility during acidification recovery, Sci. Total Environ., 409, 201-210, 2010

Lumsdon, D. G., Stutter, M. I., Cooper, R. J., and Manson, J. R.: Model assessment of biogeochemical controls on dissolved organic carbon partitioning in an acid organic soil, Environ. Sci. Technol., 39, 8057-8063, 2005.

McCartney, A. G., Harriman, R., Watt, A. W., Moore, D. W., Taylor, E. M., Collen, P., and Keay, E. J.: Long term trends in $\mathrm{pH}$, aluminium and dissolved organic carbon in Scottish fresh waters; implications for brown trout (Salmo trutta) survival, Sci. Total Environ., 310, 133-141, 2003.

Meeussen, J. C .L.: ORCHESTRA: An object-oriented framework for implementing chemical equilibrium models, Environ. Sci. Technol., 37, 1175-1182, 2003.

Meeussen, J. C. L., Kleikemper, J., Scheidegger, A. M., Borkovec, M., Paterson, E., van Reimsdijk, W. H., and Sparks, D. L.: Multicomponent transport of sulphate in a Goethite-silica sand system at variable $\mathrm{pH}$ and ionic strength, Environ. Sci. Technol., 33, 3443-3450, 1999.

Michalzik, B., Tipping, E., Mulder, J., Gallardo Lancho, J. F., Matzner, E., Bryant, C. L., Clarke, N., Lofts, S., and Vicente Esteban, M. A.: Modelling the production and transport of dissolved organic carbon in forest soils, Biogeochem., 66, 241-264, 2003.

Milne, R. and Brown, T. M.: Carbon in the vegetation and soils of Great Britain, J. Env. Manag., 49, 413-433, 1997.
Monteith, D. T., Stoddard, J. L., Evans, C.,D., de Wit, H. A., Forsius, M., Høgåsen, T., Wilander, A., Skjelkvåle, B. L., Jeffries, D. S., Vuorenmaa, J., Keller, B., Kopácek, J., and Vesely, J.: Dissolved organic carbon trends resulting from changes in atmospheric deposition chemistry, Nature, 450, 537-540, 2007.

Skelkvåle, B. L., Stoddard, J. L., Jeffries, D. S., Trseth, K., Høgåsen, T., Bownam, J., Manio, J., Monteith, D., Mosello, R., Rogora, M., Rzychon, D., Vesely, J., Wieting, J., Wilander, A., and Worsztynowicz, A.: Regional scale improvements in surface water chemistry 1990-2001, Environ. Pollut., 137, 165-176, 2005.

Smith, P., Smith, J., Flynn, H., Killham, K., Rangel-Castro, I., Foereid, B., Aitkenhead, M., Chapman, S., Towers, W., Bell, J., Lumsdon, D., Milne, R., Thomson, A., Simmons, I., Skiba, U., Reynolds, B., Evans, C., Frogbrook, Z., Bradley, I., Whitmore, A., and Falloon, P.: ECOSSE - Estimating organic carbon in organic soils, sequestration and emissions, Report to the Scottish Government, 2007.

Stoddard, J. L., Kahl, J. S., Deviney, F. A., DeWalle, D. R., Driscoll, C. T., Herlihy, A. T., Kellogg, J. H., Murdoch, P. S., Webb, J. R., and Webster, K. E.: Response of Surface Water Chemistry to the Clean Air Act Amendments of 1990, Report EPA/620/R-03/001 (US EPA, Washington DC, 2003).

Stutter, M. I., Lumsdon, D. G., and Cooper, R. J.: Temperature and soil moisture effects on dissolved organic matter release from a moorland Podzol O horizon under field and controlled laboratory conditions, Eur. J. Soil Sci., 58, 1107-1116, 2007.

Tranvik, L. J. and Jansson, M.: Terrestrial export of organic carbon, Nature, 415, 861-862, 2002.

Tipping, E.: Cation binding by humic substances, Cambridge University Press, Cambridge, ISBN 0521 621461, 434 pp., 2002.

Ussiri, D. A. N. and Johnson, C.E.: Sorption of organic carbon fractions by Spodosol mineral horizons, Soil Sci. Soc. Am. J., 68, 253-262, 2004.

Walling, D. E. and Webb, B. W.: Estimating the discharge of contaminants to coastal waters and rivers, Mar. Pollut. Bull., 16, 488-492, 1985.

Worrall, F., Burt, T., and Adamson, J.: Can climate change explain increases in DOC flux from upland peat, Sci. Total Environ., 324, 95-112, 2004a.

Worrall, F., Harriman, R., Evans, C. D., Watts, C., Adamson, J., Neal, C., Tipping, E., Burt, T. P., Grieve, I., Montieth, D., Naden, P. S., Nisbet, T., Reynolds, B., and Stevens, P.: Trends in dissolved organic carbon in UK rivers and lakes, Biogeochem., 70, 369-402, 2004b.

Wu, Y. J., Clarke, N., and Mulder, J.: Dissolved organic carbon concentrations in throughfall and soil waters at level II monitoring plots in Norway: short and long-term variations, Water Air Soil Pollut., 205, 273-288, 2010. 